\title{
せん断波速度に基づく地盤の変形係数を用いたChang 式による杭の水平抵抗評価 \\ HORIZONTAL RESISTANCE OF PILE EVALUATED BY CHANG'S FORMULA USING COEFFICIENT OF SUBGRADE REACTION CALCULATED FROM SHEAR WAVE VELOCITY
}

\author{
下村修一*，鈴木 康 嗣** \\ Shuichi SHIMOMURA and Yasutsugu SUZUKI
}

\begin{abstract}
In seismic design of pile foundation by static stress analysis, a model in which a pile is a beam and the beam and the ground are connected by multiple springs (coefficient of subgrade reaction $k_{h}$ ) is used as a practical design. In this study, we propose a method to evaluate coefficient of subgrade reaction $k_{h}$ based on shear wave velocity. We also propose a method to evaluate $k_{h}$ from inverse analyses based on the Chang's formula using past several horizontal loading test data including large diameter piles performed at in situ. Using the proposed $k_{h}$, simulation analyses by Chang's formula are carried out and the validity of the coefficient is verified.
\end{abstract}

Keywords : Single pile, Coefficient of subgrade reaction, Horizontal load test, Shear wave velocity, Pressuremeter test, Chang's formula 単杭, 水平地盤反力係数, 水平載荷試験, せん断波速度, 孔内水平載荷試験, Chang 式

\section{1.はじめに}

静的応力解析による地震時の杭の設計では，杭を曲げ剛性を有す る梁とし，この梁と地盤を複数の独立したばね(水平地盤反力係数 $\left.k_{h}\left(\mathrm{kN} / \mathrm{m}^{3}\right)\right)$ で結んだ弾性支承上の梁のモデルが実務的な検討手法と して用いられている。この手法から得られる杭の応力と水平変位は, 杭体の断面性能だけではなく, 水平地盤反力係数の評価精度に強く 依存する。水平地盤反力係数の評価方法は，Vesic ${ }^{11} ，$ Francis ${ }^{2}$ が弾 性論から，地盤の変形係数と杭幅及び杭の曲げ剛性に依存する関数 として提案している。また, 吉中 ${ }^{3)}$ は水平方向の平板載荷試験と弾 性論に基づき，杭の水平載荷試験結果との比較から，地盤の変形係 数と杭幅に依存する関数として提案している。杭幅の依存性は，久 保ら ${ }^{4)}$ ，岡原ら 5)，中谷ら 6)が水平載荷試験結果の逆解析から，古関 ら 7)が三次元 FEM による解析結果から検討している。杭の水平変 位に対する水平地盤反力係数の非線形性は, 岸田ら 8)がバイリニア モデル，神田ら 9)，関ら 10)が双曲線モデル，間瀬ら 11)が下負荷面モ デルに基づき提案している。また，一様地盤及び長い杭を仮定した 弾性支承上の梁の理論から導かれる解析解(以下, Chang 式 12),13) と 呼ぶ)に基づき, 水平載荷試験結果の逆解析から評価した水平地盤反 力係数 $k_{h}$ の非線形性は，杭体が弾性範囲内では地表面変位の $1 / 2$ 乗 に反比例することが示されている ${ }^{14)}$

一方, 各種設計指針類を見ると, 道路橋示方書 ${ }^{15)}$ 及び鉄道構造物 等設計標準 16 にには, 水平地盤反力係数を杭幅及び地盤の変形係数等 から設定し，線形またはバイリニア型のばねを用いる方法が示され ている。建築基礎構造設計指針 12)(以下，指針)には，地盤の変形係 数と杭幅から算定される基準となる水平地盤反力係数(以下, 基準水
平地盤反力係数 $k_{h 0}$ ) と，杭の無次元化水平変位に応じた非線形性を 用いる方法が示されている。指針の基準水平地盤反力係数は，地表 面位置における杭の水平変位（以下, 基準変位)が $1 \mathrm{~cm}$ 時の值であり, 非線形性は Fig.1 に示すように水平地盤反力が塑性水平地盤反力に 達するまで, 変位が $0.1 \mathrm{~cm}$ までは線形, $0.1 \mathrm{~cm}$ 以降は変位の $1 / 2$ 乗 に反比例する非線形で評価することが推奨されている。

地盤は微小ひずみから非線形化が進み破壊に至るため，地盤反力 一変位関係は PS 検層に基づく微小ひず夕時の初期剛性と, 強度定 数 $(C, \phi)$ に基づく極限地盤反力, 並びに両者を結ぶ非線形性を深さ 毎に評価することが理想的である。しかし，指針における水平地盤 反力係数の非線形性は, Chang 式 12),13)を用いた水平載荷試験の杭 頭荷重一杭頭変位関係の逆解析から求められているため ${ }^{14)}$, 杭全長 にわたり平均化された地盤の塑性状態を反映していることになる。

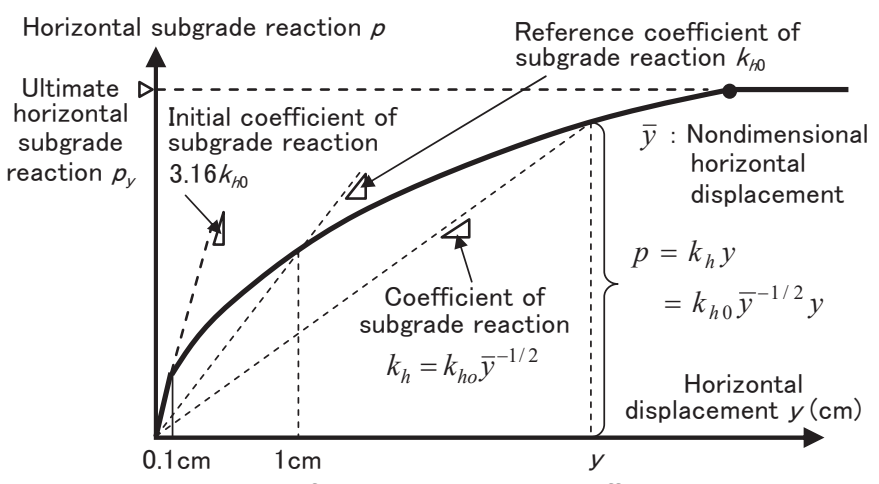

Fig.1 Evaluation of subgrade reaction coefficient based on recommendations for design of building foundations

\footnotetext{
* 日本大学生产工学部建築工学科 専任講師 ·博士 (工学)

Assist. Prof., Dept. of Architecture and Architectural Engineering, College of Industrial Technology, Nihon University, Dr.Eng.

**＼cjkstart鹿島建設技術研究所都市防災風環境グループ グループ長・博士(工学) 
一方, 基準水平地盤反力係数の算定式は, 地盤の変形係数評価に孔 内水平載荷試験結果を用いて誘導されている3)が, この変形係数 $E_{b}$ を評価している地盤の圧縮ひずみ $\varepsilon$ は数\%のオーダーで試験毎に異 なる。また, 杭の水平載荷試験では, 地盤内の応力や変位は杭径が 大きいほど深度方向と杭前面方向に遠くまで伝わるため, 杭径によ つて杭頭変位 $1 \mathrm{~cm}$ 時の杭前面地盤の平均的な水平方向圧縮ひずみ は異なり, 孔内水平載荷試験との対応は明確ではない。さらに, 指 針の水平地盤反力係数は, 著者らの検討 ${ }^{17), 18)}$ により, 小さめの值と なることを確認している。この小さめの值は杭頭慣性力を対象とし た場合には設計上安全側となるが，地盤変形を考えると地中部にお いて危険側となるため, 両者に適用するにはばらつきを狭めた上で 平均的な值を設定する必要があると著者らは判断している。

古関ら 7)は，杭の一部を水平方向に押込んだ場合を対象に三次元 FEM 解析を行い, 杭の水平地盤反力係数が杭水平変位よりも杭水 平変位/杭径と高い相関があることを示している。また, 著者らは砂 質土に関しては $\mathrm{N}$ 值, 粘性土に関しては一軸圧縮強さ $q_{u}$ に基づき, 杭の水平載荷試験における水平地盤反力係数と杭頭変位/杭径との 相関を提示している 17),18)。

そこで本研究では, 第 2 章で既往の孔内水平載荷試験結果から地 盤のひずみレベルの影響を検討し, 地盤の変形係数評価にせん断波 速度を用いる方法を提案した。次に, 第 3 章で既往の水平載荷試験 結果を用いた Chang 式 12),13)に基づく逆解析結果から, 大口径杭を 含む水平地盤反力係数 $k_{h}$ の基準変位, 杭径及び地表面変位に対する 依存性を検討した。さらに第 4 章, 第 5 章で Chang 式を用いたシ ミュレーション解析と第 3 章までの結果を踏まえて大口径杭を含む 水平地盤反力係数 $k_{h}$ の設定方法を提案した。なお, 本研究の内容は Chang 式に基づき逆算水平地盤反力係数 $k_{h}$ を評価しているため, 一 様地盤中の杭頭自由条件の単杭において地盤変位の影響が小さい条 件下で杭頭慣性力が作用した場合に適用できるものである。

\section{2. 地盤のひずみレベルを考慮した地盤の変形係数評価}

指針の水平地盤反力係数評価式に用いられる地盤の変形係数は, 孔内水平載荷試験結果が基となっている。本章では, 既往の孔内水 平載荷試験結果から地盤のひずみレベルの影響を検討し, せん断波 速度を用いて基準水平地盤反力係数を求める方法を提案する。

指針の水平抵抗算定式による評価では，単杭の基準水平地盤反力 係数を(1)式で算定する。

$$
k_{h 0}=\alpha E_{S} \bar{B}^{n}
$$

ここに, $k_{h 0}$ : 基準水平地盤反力係数 $\left(\mathrm{kN} / \mathrm{m}^{3}\right), \alpha$ : 係数(80, 粘性 土の変形係数を $\mathrm{N}$ 值から算出する場合は 60$), E_{S}$ : 地盤の变形係数 $\left(\mathrm{kN} / \mathrm{m}^{2}\right), \bar{B}$ : 無次元化杭径(杭径を $\mathrm{cm}$ で示した無次元数值), $n$ : 杭径依存に関する指数で指針ではー $3 / 4$ である。指針には, 地盤の 変形係数 $E_{S}$ を $\mathrm{N}$ 值から評価する場合，(2)式が示されている。

$$
E_{S}=700 \mathrm{~N}
$$

ここに, $N: \mathrm{N}$ 值である。また, 著者らはよりばらつきの小さな 水平地盤反力係数を与える地盤の変形係数評価式として, 砂質土で

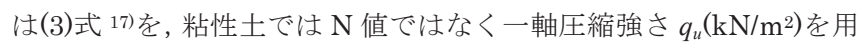
いた(4)式 18)を提案している。

$$
\begin{aligned}
& E_{S}=700(N+3) \\
& E_{S}=50 q_{u}
\end{aligned}
$$

なお，(3)式は $\mathrm{N}$ 值 $\geqq 3$ の砂質土に用いることとしている。

Fig. 2 に孔水平載荷試験(LLT 試験) から求めた変形係数 $E_{b}$ と $\mathrm{N}$ 值(半自動落下装置)及び一軸圧縮強さ $q_{u}$ の関係を示す。同図には (2) 〜 (4)式と最小二乗法によるデータ群毎の累乗近似式とその相関係 数 $R$ を併記した。Fig.2 より, 一軸圧縮強さ $q_{u}$ のデータは少なく判 断し難いものの, $E_{b}$ と $\mathrm{N}$ 值の関係は大きくばらつくこと, このばら つきは粘性土でより顕著なこと,及び指針に用いられている(2)式は $\mathrm{N}$ 值が低い砂質土と粘性土で低めの值を与えるとともに傾きが異な ることが分かる。

Fig.2 で使用した孔内水平載荷試験結果において, $E_{b}$ の評価に用 いている孔壁位置の半径方向ひずみ $\varepsilon_{r}{ }^{19), 20)}$ と $\mathrm{N}$ 值及び一軸圧縮強さ $q_{u}$ の関係を Fig.3 に示す。同図にはデータ群毎の平均值を破線で併 記している。Fig.3 より, 孔内水平載荷試験結果における地盤のひ ずみは $\mathrm{N}$ 值が小さい場合には 1 オーダーものばらつきがあり,これ が Fig.2 で確認されたばらつきの一因と考えられる。

地盤のひずみを揃えた検討を行うには，孔内水平載荷試験と同じ 条件下における地盤の変形係数のひずみ依存関係を用いる必要があ るが，このような関係を検討した研究は見当たらない。そこで，孔 内水平載荷試験から求まる半径方向ひずみと変形係数 $E_{b}$ の関係と, 既往の地盤の動的変形特性に用いられているひずみ依存曲線 21) 23) を比較して Fig.4 に示す。なお, 文献 22$)$ には平均と $\pm \sigma(\sigma$ : 標準偏 差)の幅が示されているため, $\pm \sigma$ の範囲を示した。縦軸は孔内水平 載荷試験から求めた変形係数 $E_{b}$ を, (5)式でせん断波速度から算出 した初期変形係数 $E_{0}$ で除した剛性低下率 $E_{b} / E_{0}$ と, 既往の動的変形

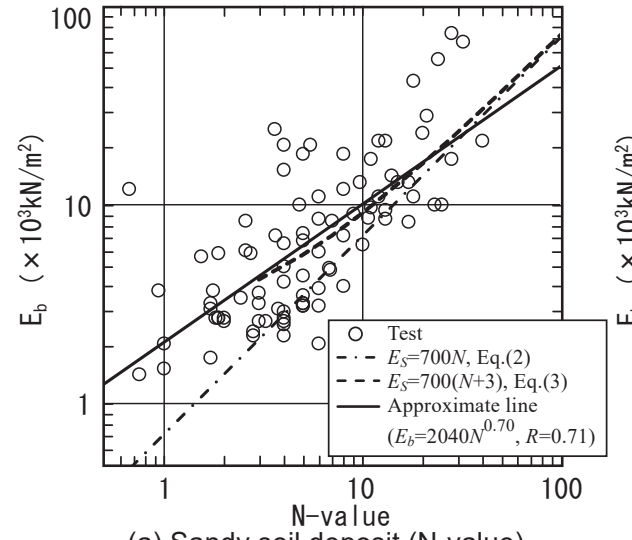

(a) Sandy soil deposit ( $\mathrm{N}$-value)

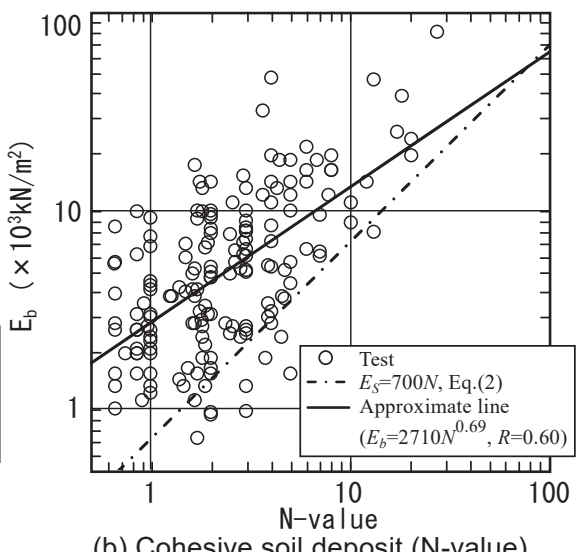

(b) Cohesive soil deposit ( $\mathrm{N}$-value)

ig.2 Relationships among $\mathrm{N}$-value, $q_{u}$ and $E_{b}$

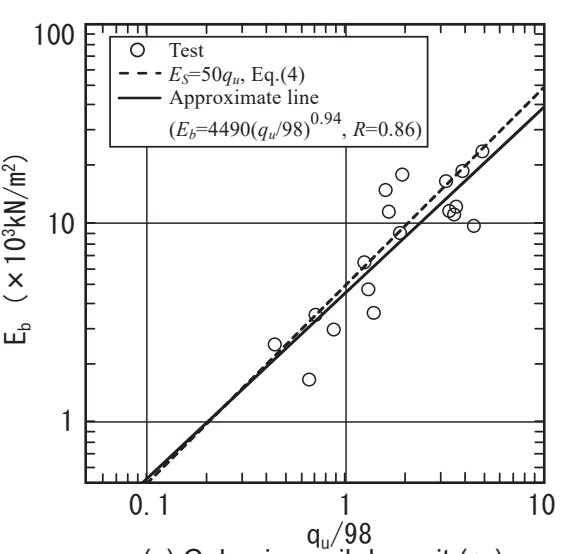

(c) Cohesive soil deposit $\left(q_{u}\right)$ 


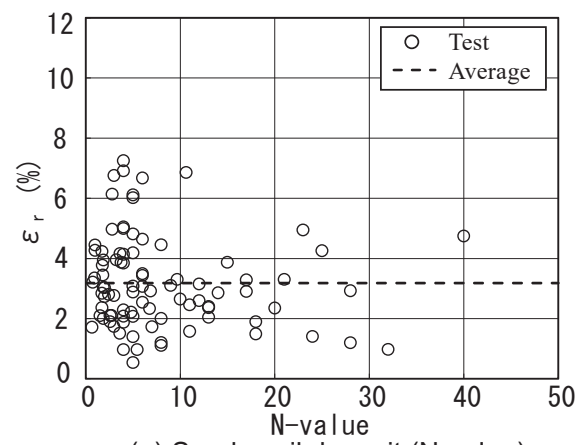

(a) Sandy soil deposit ( $\mathrm{N}$-value)

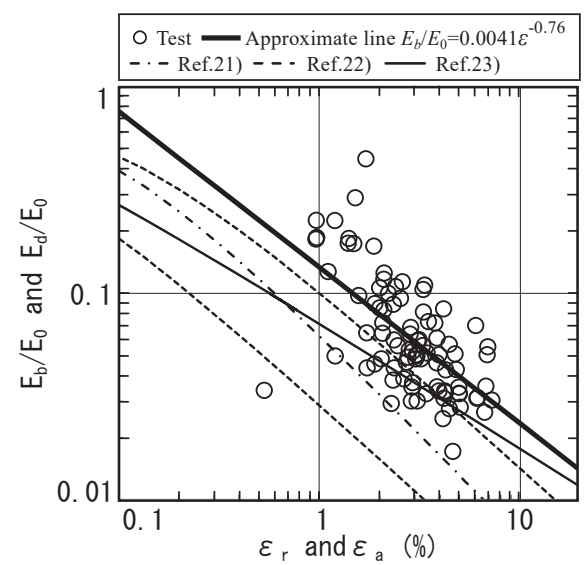

(a) Sandy soil deposit ( $\mathrm{N}$-value)

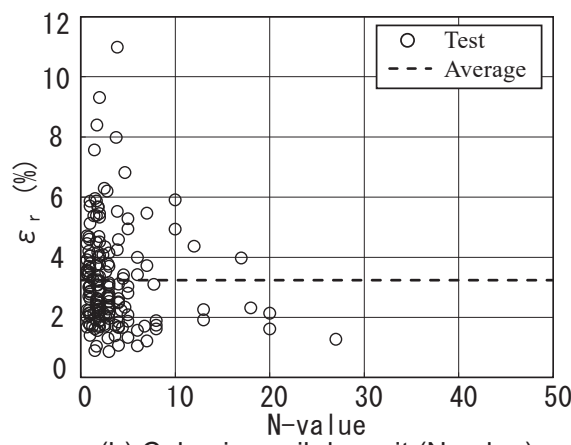

(b) Cohesive soil deposit ( $\mathrm{N}$-value)

Fig.3 Relationships among $\mathrm{N}$-value, $q_{u}$ and $\varepsilon_{r}$

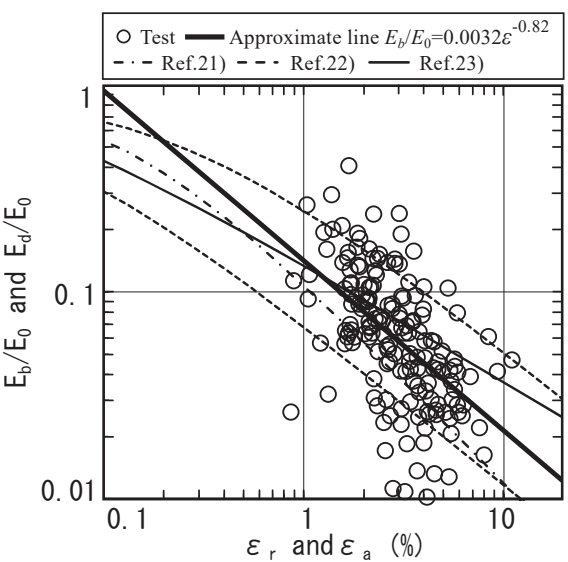

(b) Cohesive soil deposit ( $N$-value)

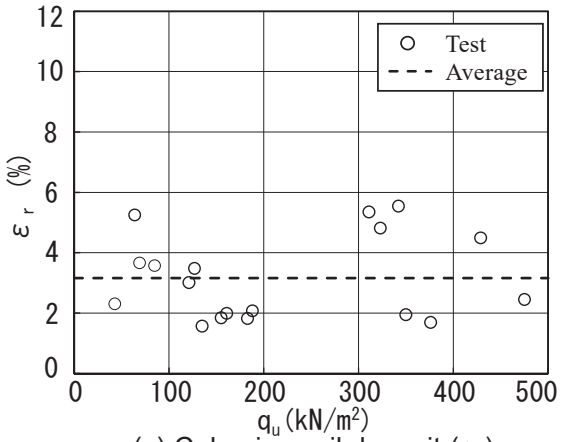

(c) Cohesive soil deposit $\left(q_{u}\right)$

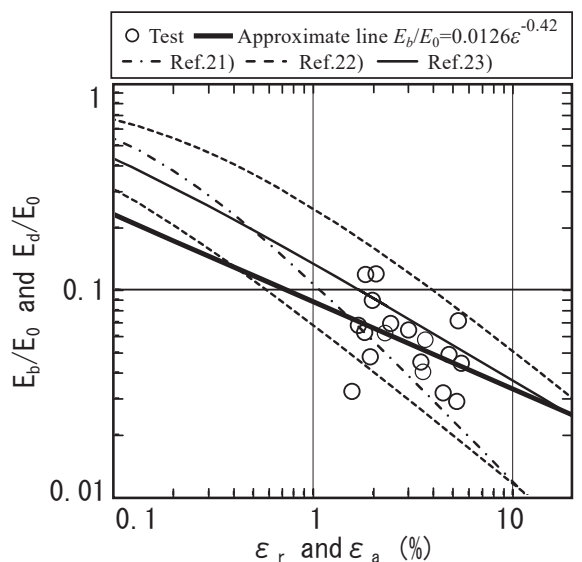

(c) Cohesive soil deposit $\left(q_{u}\right)$

Fig.4 Tendency of strain-dependent stiffness variations

試験から求めた剛性低下率 $E_{d} / E_{0}$, 横軸は孔内水平載荷試験から求め た半径方向ひずみ $\varepsilon_{r}$ と動的変形試験の軸ひずみ $\varepsilon_{a}$ とした。なお, PS 検層と孔内水平載荷試験を同一地点で実施しているデータが少ない ため，せん断波速度は(6)，(7)式 24)及び(8)式 25)を用いて $\mathrm{N}$ 值， $q_{u}$ から推定した。(6), (7)式の適用範囲を超える $\mathrm{N}$ 值 1 未満も外挿し て用いた。なお，せん断波速度の推定式は種々提案されており，ば らつきも大きいため以後の検討結果は推定式に依存するが，パラメ 一タが比較的少ない文献 24), 25)を採用した。

$$
E_{0}=2 G_{0}(1+v)=2(1+v) \rho V_{S}^{2}
$$

（砂質土） $V_{S}=80 N^{1 / 3}$

（粘性土） $V_{S}=100 N^{1 / 3}$

（粘性土） $V_{S}=134\left(q_{u} / 98\right)^{0.443}$

ここに, $G_{0}$ : 初期せん断弾性係数 $\left(\mathrm{kN} / \mathrm{m}^{2}\right), v$ : ポアソン比 $(0.5$ を 仮定), $V_{S}$ : せん断波速度 $(\mathrm{m} / \mathrm{s}), \rho$ : 単位体積質量(砂質土 $: 1.8 \mathrm{t} / \mathrm{m}^{3}$, 粘性土 : $1.5 \mathrm{t} / \mathrm{m}^{3}$ を仮定 $), q_{u}$ : 一軸圧縮強さ $\left(\mathrm{kN} / \mathrm{m}^{2}\right)$ である。また, 既往の剛性低下曲線は, せん断弾性係数の低下率とせん断ひずみ $\gamma$ の関係であるが，動的変形試験は基本的に飽和土の非排水試験であ るため, Fig.4 には砂質土と粘性土のポアソン比を 0.5 と仮定してせ ん断ひずみ $\gamma$ を軸ひずみ $\varepsilon_{a}$ に変換して示している。なお，いずれの 既往の関係も各文献で示されている試験データの範囲を超えた領域 まで外挿している。Fig.4 より, 孔内水平載荷試験から求めた剛性 低下率 $E_{b} / E_{0}$ と半径方向ひずみ $\varepsilon_{r}$ の関係には，ひずみが大きいほど 岡性が低下寸る傾向が認められるが動的変形試験とは必ずしも一致 していない。これは, 孔内水平載荷試験の半径方向ひずみは載荷面 近傍の局所的な地盤変形の影響を強く受け, 動的変形試験のひずみ とは定義が異なるためと判断される。
そこで, Fig.4 の最小二乗法によるデータ群毎の累乗近似式を用 い, 変形係数 $E_{b}$ を Fig. 3 に示した半径方向ひずみの平均值 $3 \%$ 相当 の変形係数 $E_{b}{ }^{\prime}$ に変換して Fig.5 に示す。Fig.5 には(5)〜(8)式で算定 した結果, 最小二乗法でデータ群毎に $\mathrm{N}$ 值及び $q_{u}$ を累乗近似した $(9) \sim(11)$ 式, $-\sigma,-2 \sigma(\sigma$ : 標準偏差 $)$ 関係並びに $(2) \sim(4)$ 式の関係 を併記している。

$$
\begin{aligned}
& \text { （砂質土） } \quad E_{b}^{\prime}=2160 N^{0.63} \\
& \text { (粘性土) } \quad E_{b}^{\prime}=2810 N^{0.61} \\
& \text { (粘性土) } \quad E_{b}^{\prime}=4400\left(q_{u} / 98\right)^{0.94}
\end{aligned}
$$

Fig.5 の関係は Fig.2 と比べて累乗近似式の相関係数 $R$ が大きく なり, 累乗近似式の傾きはせん断波速度から(6)〜 (8)式で求めた関係 とほぼ一致している。また, データの中央付近で(9)〜(11)式の傾き を(6)〜(8)式に合わせたラインで比較した場合, (9)〜(11)式の累乗近 似式から求めた $E_{b}{ }^{\prime}$ は, (6) (8)式から得られる $E_{0}$ と比べて, 砂質土 で $E_{0} / 17\left(\mathrm{~N}\right.$ 值), 粘性土で $E_{0} / 18(\mathrm{~N}$ 值 $), E_{0} / 18\left(q_{u}\right)$ に相当する。累乗近 似式の $-\sigma,-2 \sigma$ の $E_{b}{ }^{\prime}$ は, $\mathrm{N}$ 值を用いた場合は砂質土で $E_{0} / 28, E_{0} / 46$, 粘性土で $E_{0} / 32, E_{0} / 59, q_{u}$ を用いた場合は $E_{0} / 26, E_{0} / 37$ に相当する。 動的変形試験から得られる地盤の剛性低下率は, 同じひずみでは砂 質土よりも粘性土の方が大きい21) 23)が，この傾向は Fig.5 からは 認められない。また, 著者らが提案している(3)式 17)，(4)式 18)は, (9), (11)式と比較して砂質土では $\mathrm{N}$ 值が 3 30 の範囲で, 粘性土で は幅広い $q_{u}$ 值の範囲でほぼ同程度の変形係数を与える。

以上より, データ量やラインの引き方で変わる可能性があるもの の, 孔内水平載荷試験から推定される変形係数 $E_{b}{ }^{\prime}$ はせん断波速度か ら求めた変形係数 $E_{0}$ を砂質土, 粘性土ともに $1 / 18$ 程度に低下させ ることで平均的な評価が可能である。また, ばらつきを考慮して安 


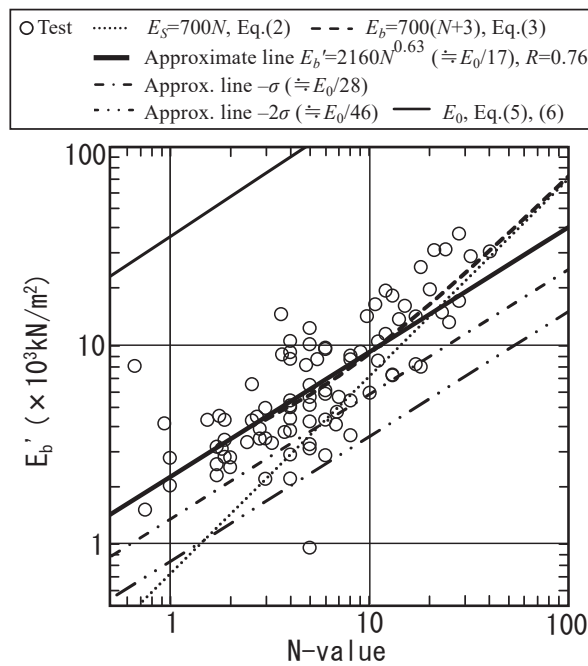

(a) Sandy soil deposit ( $\mathrm{N}$-value)

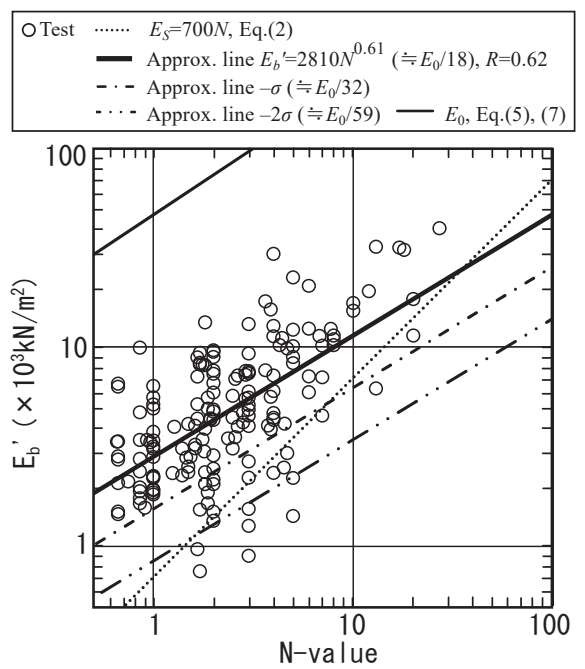

(b) Cohesive soil deposit ( $\mathrm{N}$-value) g. 5 Relationships among $\mathrm{N}$-value, $q_{u}$ and $E_{b}{ }^{\prime}$

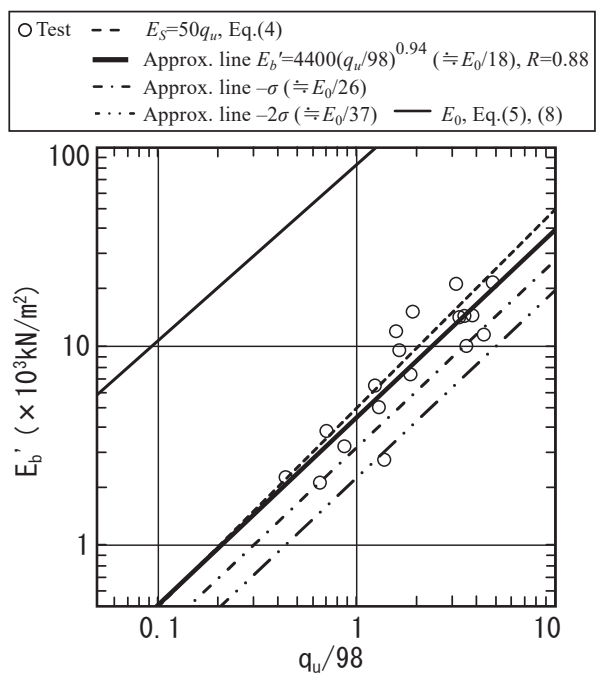

(c) Cohesive soil deposit $\left(q_{u}\right)$
全側に評価 $(-\sigma)$ すると $\mathrm{N}$ 值を用いた場合は砂質土，粘性土ともに $E_{0} / 30$ 程度, $q_{u}$ を用いた場合は $E_{0} / 25$ 程度と判断される。

\section{3. 水平載荷試験及び逆算 $k_{h}$ の杭径依存性}

水平載荷試験結果に対して Chang 式 12),13)に基づく杭頭荷重一杭 頭変位関係の逆解析から逆算水平地盤反力係数 $k_{h}$ を評価し, 基準水 平地盤反力係数の設定方法とその評価に用いる基準変位，杭径及び 地表面変位に対寸る依存性について検討した。Table1に対象とした 水平載荷試験結果の一覧 17),18) 示す。なお，文献 17)，18)からデー 夕を見直しており, 両土質ともに 1 試験ずつ除外している。全て国 内における杭頭拘束条件が自由な単杭である。H250 と $\phi 400 \sim 1100$ の 28 データ(以下，小口径杭と定義) と $\phi 1200 \sim 3000 \mathrm{~mm}$ と壁厚 $600 \mathrm{~mm}$ で壁幅 B2200 6600mm の 11 データ(以下，大口径杭と定 義)を対象とした。なお，杭の載荷試験結果及び地盤調查結果の数值 が示されていない場合は，グラフから数值を読み取っている。

粘性土における試験には, 地盤の一軸圧縮強さが得られている試 験結果を選定したが，一部を除き $\mathrm{N}$ 值も得られている。Table1 の $\mathrm{N}$ 值，一軸圧縮強さ $q_{u}$ 及びせん断波速度 $V_{S}$ は，地表面から杭の特 性值 $\beta$ の逆数 $(1 / \beta)$ の範囲の平均值とした。杭の特性值 $\beta$ は, Chang 式 12),13)を用いた収束計算により水平載荷試験の地表面変位 $1 \mathrm{~cm}$ 時 の逆算水平地盤反力係数 $k_{h}$ を求めて(12)式から算出した。

$$
\beta=\sqrt[4]{\frac{k_{h} B}{4 E I}}
$$

ここに, $k_{h}$ : 水平地盤反力係数 $\left(\mathrm{kN} / \mathrm{m}^{3}\right), B$ : 杭径 $(\mathrm{m}), E$ : 杭のヤ ング率 $\left(\mathrm{kN} / \mathrm{m}^{2}\right), I$ : 杭の断面 2 次モーメント $\left(\mathrm{m}^{4}\right)$ である。杭のヤン グ率や断面 2 次モーメントは各文献に記載されている值を用いた。 ヤング率が文献に記載されていない場合，コンクリートは $2.05 \times$ $10^{7} \mathrm{kN} / \mathrm{m}^{2}$ ，鋼材は $2.05 \times 10^{8} \mathrm{kN} / \mathrm{m}^{2}$ を仮定した。

なお，地表面付近が比較的一様な地盤でせん断波速度を計測して いる水平載荷試験結果を確認できなかったため，対象試験にはせん 断波速度のデータがない。そこで，せん断波速度VS は各深度の $\mathrm{N}$ 值及び一軸圧縮強さ $q_{u}$ から (6)〜 (8)式で算出した後, 平均している。

表層部の土質構成は比較的単純で, 平均 $\mathrm{N}$ 值が $3 \sim 16$ の比較的緩 い砂質土, 平均一軸圧縮強さ $q_{u}$ が $18 \sim 234 \mathrm{kN} / \mathrm{m}^{2}$ 及び平均 $\mathrm{N}$ 值が 0
〜5の軟弱な粘性土で実施された試験結果が多い。ただし，一部で は地表から $1 / \beta$ の範囲に砂質土では粘性土, 粘性土では砂質土を挟 んでいる。そこで, 地盤の変形係数の評価では砂質土と粘性土の層 厚毎にパターン分けをした。まず砂質土では, Fig.6 に示すように 多くの地盤は深度 $1 / \beta$ までの範囲に粘性土層を含まないパターン $\mathrm{S}$ I である。粘性土層厚の合計が $0.1 / \beta$ 以下であるパターン S II では, 粘性土層の影響は小さいと判断して無視した。粘性土層厚の合計が $0.1 / \beta \sim 0.33 / \beta$ 程度あるパターン SIII では, 粘性土も含めて変形係数 を $\mathrm{N}$ 值から算出した。なお, 粘性土層厚の合計が $0.33 / \beta$ 以上の場合 は検討対象としていない。粘性土ではほとんどがパターン C I で, 一部で砂質土層厚が 0.1/ $\beta$ 以下のパターン C II があるが, 影響は小さ いと判断して砂質土と同様に無視した。なおパターンCIII はない。

Fig.7 に杭頭水平荷重と載荷点位置における杭水平変位の関係を 砂質土と粘性土，小口径杭 $(\mathrm{S} 1 \sim 15, \mathrm{C} 1 \sim 13)$ と大口径杭 $(\mathrm{S} 16 \sim 22$, C14 17)に分けて示す。なお, 論文中に杭頭水平荷重と載荷点位置 における杭水平変位の関係が示されていない場合は後述する Chang 式で逆算した。以後の検討では, 文献内の記述を参考に杭体 が弾性範囲内のデータを対象とするが, 水平載荷試験から杭体降伏 の有無が明確でない場合, 後述の 4 章のシミュレーション解析結果 を参考に弾性範囲内のデータのみを対象とした。

Chang 式 12),13)では，杭の載荷点位置における変位 $y_{t o p}(\mathrm{~m})$ は(13) 式で表される。なお, 全ての実験データは $\beta L(\beta$ : 杭の特性值, $L$ : 杭長) が 2.25 を上回るため, 十分に長い杭と判断され, 曲げ変形の みを考慮している Chang 式が適用可能であると判断した。

$$
y_{\text {top }}=\frac{(1+\beta h)^{3}+1 / 2}{3 E I \beta^{3}} H+\frac{(1+\beta h)^{2}}{2 E I \beta^{2}} M_{t o p}
$$

ここに, $h$ :地表面から載荷点までの距離 $(\mathrm{m}), H$ : 載荷水平力 $(\mathrm{kN})$, $M_{t o p}$ : 載荷点位置の曲げモーメント $(\mathrm{kN} \cdot \mathrm{m})$ である。本研究で対象 とした試験は杭頭自由条件であるため， $M_{t o p}$ はゼロとし，(13)式で 得られる杭の特性值 $\beta$ を用いて(12)式から逆算 $k_{h}$ を算出した。また, 地表面位置における杭変位 $y(\mathrm{~m})$ は(14)式で求まる。

$$
y=\frac{1+\beta\left(h+h_{0}\right)}{2 E I \beta^{3}} H
$$

ここに, $h_{0}=M_{t o p} / H=0$ である。指針の水平抵抗算定式では, 単杭の 
基準水平地盤反力係数を(1)式で評価する。本章では，(1)式に用いる 変形係数を 2 章の検討結果に基づき(15)式で算出した。また, 表記 を揃えるため，(1)式を(1)'式に変えた。

$$
\begin{aligned}
& E_{S}=E_{0} / 18 \\
& k_{h 0}=\alpha E_{S}\left(B / B_{0}\right)^{n}
\end{aligned}
$$

ここに， $B_{0}$ は $1.0 \mathrm{~cm}$ である。 $E_{0}$ は，(6)，(8)式で求めた Table1 に示すせん断波速度を用いて(5)式で算出した。

逆算 $k_{h}$ を, 指針の方法に従い(1)’式(地盤の変形係数 $E_{S}$ は(2)式を 使用，参考として(3)，(4)式も使用)から算定した推定 $k_{h 0}$ で除した逆
算 $k_{h} /$ 推定 $k_{h 0}$ と, 地表面位置の杭変位(以後, 杭頭変位)の関係を砂質 土と粘性土に分けて Fig. 8 に示す。なお， N 值が 0.5 以下のデータ は検討対象から除外した。同図には指針の水平地盤反力係数 $k_{h}$ が杭 頭変位の $1 / 2$ 乗に反比例する(16)，（17）式の関係を破線で，(18)式 の最小二乗法による累乗近似線を実線で併記した。なお，(16)，(18) 式は表記を揃えるため，指針の $\bar{y}$ を $y_{0}=1 \mathrm{~cm}$ として $y / y_{0}$ に変えた。

$$
\begin{aligned}
& \left(y>0.1 y_{0}\right) \quad k_{h} / k_{h 0}=\left(y / y_{0}\right)^{-1 / 2} \\
& \left(y \leqq 0.1 y_{0}\right) \quad k_{h} / k_{h 0}=3.16 \\
& k_{h} / k_{h 0}=a\left(y / y_{0}\right)^{x}
\end{aligned}
$$

\begin{tabular}{|c|c|c|c|c|c|c|c|c|}
\hline \multirow[b]{2}{*}{ No. } & \multicolumn{3}{|c|}{ Pile } & \multicolumn{4}{|c|}{ Ground properties } & \multirow{2}{*}{$\begin{array}{c}\text { Bending } \\
\text { moment } \\
\text { data }\end{array}$} \\
\hline & $\begin{array}{c}\text { Diameter } \\
(\mathrm{mm})\end{array}$ & Type & $\begin{array}{l}\text { Length } \\
(\mathrm{m})\end{array}$ & Soil type & $\begin{array}{c}\mathrm{N} \\
\text { value }\end{array}$ & $\begin{array}{c}\begin{array}{c}V s \\
(\mathrm{~m} / \mathrm{s})\end{array} \\
\end{array}$ & $\begin{array}{c}\text { Pattern } \\
\text { (Fig.6) }\end{array}$ & \\
\hline $\mathrm{S1}$ & 400 & Concrete filling steel pipe & 15.0 & Fine sand & 12 & 183 & S I & \\
\hline $\mathrm{S} 2$ & 508 & Steel pipe & 8.0 & Sand with gravel & 3 & 115 & SIII & \\
\hline S3 & 508 & Steel pipe & 8.0 & Sand with gravel & 3 & 113 & SIII & \\
\hline S4 & 600 & $\begin{array}{l}\text { Hybrid steel pipe } \\
\text { with soil cement }\end{array}$ & 24.1 & Sand with gravel & 5 & 137 & S I & \\
\hline S5 & 609.6 & Steel pipe & 14.7 & Fine sand & 5 & 137 & S II & \\
\hline 56 & 609.6 & Steel pipe & 12.6 & Fine sand & 5 & 137 & S II & \\
\hline S7 & 609.6 & Steel pipe & 24.0 & Fine sand & 12 & 178 & S I & $v$ \\
\hline s8 & 800 & $\begin{array}{l}\text { Hybrid steel pipe } \\
\text { with soil cement }\end{array}$ & 25.8 & Sand & 3 & 113 & S I & \\
\hline s9 & 800 & Steel pipe & 26.4 & Fine sand & 7 & 153 & SIII & \\
\hline S10 & 914.4 & Steel pipe & 26.0 & Sand & 3 & 111 & S I & $v$ \\
\hline S11 & 914.4 & Steel pipe & 26.0 & Sand & 3 & 111 & S I & $\boldsymbol{V}$ \\
\hline $\mathrm{S} 12$ & 914.4 & Steel pipe & 26.0 & Sand & 3 & 113 & S I & \\
\hline S13 & 1000 & Steel pipe & 46.0 & Fine sand & 10 & 158 & S I & $\boldsymbol{v}$ \\
\hline S14 & 1072.2 & Steel pipe & 19.5 & Sand & 5 & 135 & S I & \\
\hline S15 & 1072.2 & Steel pipe & 19.5 & Sand & 5 & 135 & S I & \\
\hline S16 & 1200 & Cast-in-place concrete pile & 21.6 & Fine sand & 16 & 203 & S I & $v$ \\
\hline S17 & 2200 & Cast-in-place concrete pile & 40.0 & Sand & 5 & 133 & SIII & \\
\hline S18 & 2200 & Cast-in-place concrete pile & 70.0 & Sand & 5 & 134 & SIII & \\
\hline S19 & 3000 & Cast-in-place concrete pile & 70.0 & Sand & 6 & 144 & SIII & \\
\hline S20 & 2200 & $\begin{array}{l}\text { Cast-in-place concrete pile } \\
\text { with rectangular section } \\
\text { (Short side width:600mm) }\end{array}$ & 19.7 & Sand & 9 & 167 & S I & $\checkmark$ \\
\hline S21 & 4400 & $\begin{array}{l}\text { Cast-in-place concrete pile } \\
\text { with rectangular section } \\
\text { (Short side width: } 600 \mathrm{~mm} \text { ) }\end{array}$ & 19.7 & Sand & 9 & 166 & S I & $\checkmark$ \\
\hline S22 & 6600 & $\begin{array}{l}\text { Cast-in-place concrete pile } \\
\text { with rectangular section } \\
\text { (Short side width: } 600 \mathrm{~mm} \text { ) }\end{array}$ & 19.7 & Sand & 9 & 166 & S I & $v$ \\
\hline
\end{tabular}

\begin{tabular}{|c|c|c|c|c|c|c|c|c|c|}
\hline \multirow[b]{2}{*}{ No. } & \multicolumn{3}{|c|}{$\begin{array}{l}\text { Pile } \\
\text { Pill }\end{array}$} & \multicolumn{5}{|c|}{ Ground properties } & \multirow{2}{*}{$\begin{array}{c}\text { Bending } \\
\text { moment } \\
\text { data }\end{array}$} \\
\hline & $\begin{array}{c}\text { Diameter } \\
(\mathrm{mm})\end{array}$ & Type & $\begin{array}{c}\text { Length } \\
(\mathrm{m})\end{array}$ & Soil type & $\begin{array}{c}\left.\mathrm{q}_{\mathrm{u}}{ }^{*}\right) \\
\left(\mathrm{kN} / \mathrm{m}^{2}\right) \\
\end{array}$ & $\begin{array}{c}\mathrm{N} \\
\left.\text { value }^{*}\right)\end{array}$ & \begin{tabular}{|c|}
$\begin{array}{c}\text { Vs } \\
(\mathrm{m} / \mathrm{s})\end{array}$ \\
\end{tabular} & \begin{tabular}{|c} 
Pattern \\
(Fig.6)
\end{tabular} & \\
\hline C1 & 250 & $\mathrm{H}$-shaped steel pile & 5.5 & Loam & 88 & 3 & 127 & C I & $\checkmark$ \\
\hline $\mathrm{C} 2$ & 400 & PC & 25 & Clay & 30 & 0 & 79 & C I & \\
\hline $\mathrm{C} 3$ & 400 & Concrete filling steel pipe & 18 & Sandy silt & 60 & 2 & 107 & C I & \\
\hline $\mathrm{C} 4$ & 400 & Prestressed concrete pile & 22 & Loam & 234 & 3 & 195 & C I & \\
\hline $\mathrm{C} 5$ & 600 & PRC & 18 & Loam & 24 & 0 & 71 & $\mathrm{CI}$ & \\
\hline $\mathrm{C} 6$ & 600 & $\mathrm{PC}$ & 10 & Clayey silt & 27 & 2 & 75 & $\mathrm{CI}$ & \\
\hline $\mathrm{C} 7$ & 600 & $\mathrm{SC}$ & 36 & Silty clay & 40 & 0 & 89 & $\mathrm{CI}$ & \\
\hline $\mathrm{C} 8$ & 609.6 & Steel pipe & 28.7 & Peat & 18 & - & 63 & $\mathrm{CI}$ & $\checkmark$ \\
\hline C9 & 609.6 & Steel pipe & 28.7 & Peat & 18 & - & 63 & C I & \\
\hline $\mathrm{C} 10$ & 609.6 & Steel pipe & 18 & Loam & 24 & 0 & 71 & C I & $v$ \\
\hline C11 & 1000 & Steel pipe & 17.5 & Tuffaceous clay & 57 & 5 & 105 & C I & $v$ \\
\hline C12 & 1000 & Concrete filling steel pipe & 23.5 & Sandy silt & 60 & 2 & 107 & C I & $v$ \\
\hline $\mathrm{C} 13$ & 1000 & Concrete filling steel pipe & 21 & Sandy silt & 60 & 2 & 107 & C I & \\
\hline C14 & 1524 & Steel pipe & 43 & Clay & 20 & - & 66 & $\mathrm{CII}$ & \\
\hline $\mathrm{C} 15$ & 1548 & Cast-in-place concrete pile & 30 & Clay & 65 & 1 & 111 & C I & $\checkmark$ \\
\hline C16 & 2000 & Cast-in-place concrete pile & 30 & Clay & 65 & 1 & 111 & C I & \\
\hline C17 & 2200 & $\begin{array}{l}\text { Cast-in-place concrete pile } \\
\text { with rectangular section } \\
\text { (Short side width: } 600 \mathrm{~mm} \text { ) }\end{array}$ & 16.5 & Loam & 160 & 4 & 165 & C I & \\
\hline
\end{tabular}

Table 1 Outline of past horizontal load tests of single pile (a) Sandy soil deposit ${ }^{17)}$

(b) Cohesive soil deposit ${ }^{18)}$

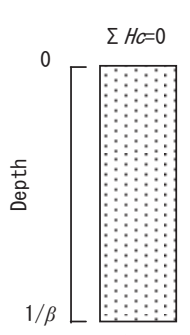

Pattern SI

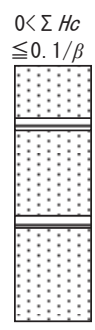

S II

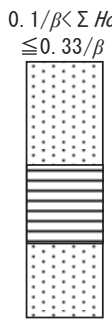

SIII
Fig. I Ground layer pattern

※) Average from $0 \mathrm{~m}$ to $1 / \beta \mathrm{m}$ depth

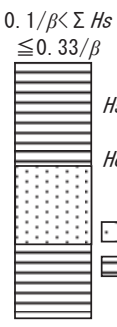

CIII
: Layer thickness of sandy soil Hc: Layer thickness of cohesive soil

$\rightarrow$ Sandy soil Cohesive soil

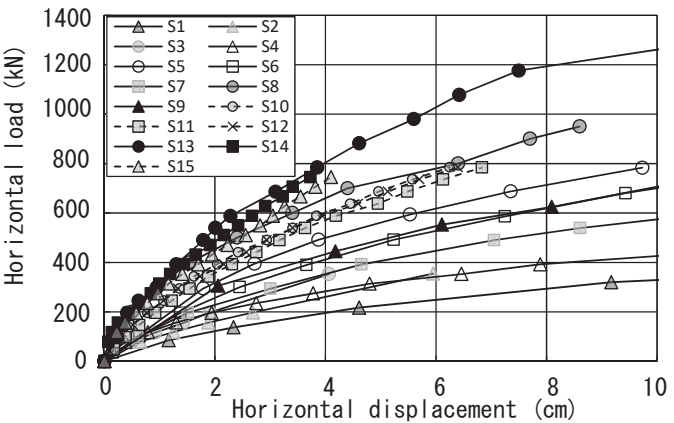

(a-1) Small diameter piles in sandy soil deposit

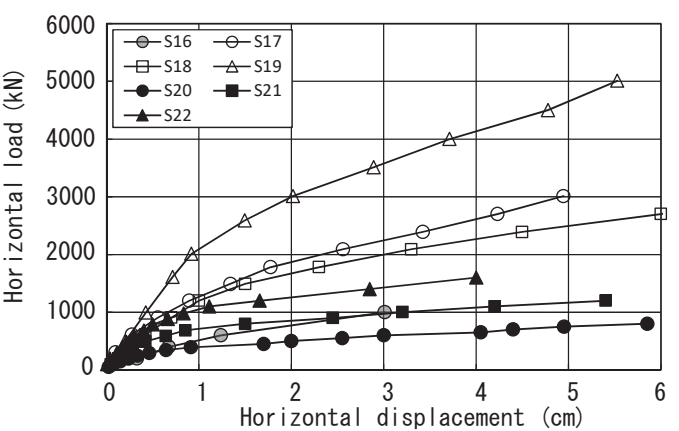

(a-2) Large diameter piles in sandy soil deposit

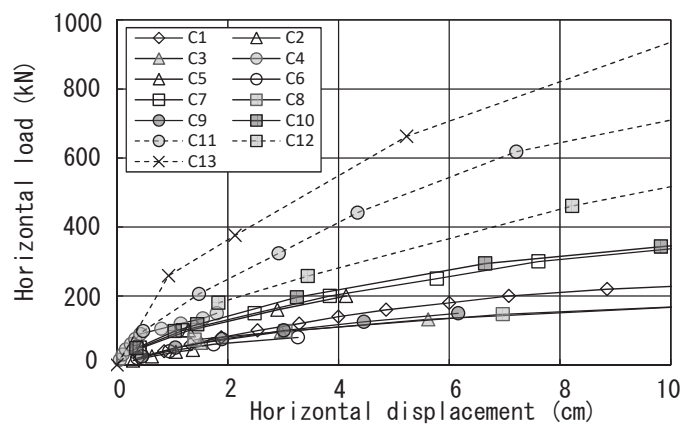

(b-1) Small diameter piles in cohesive soil deposit

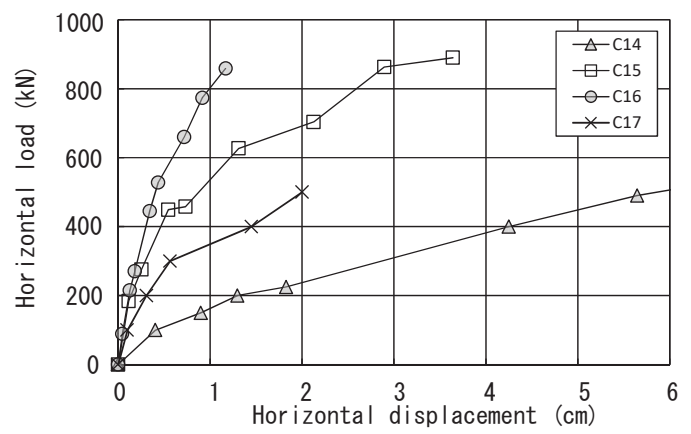

(b-2) Large diameter piles in cohesive soil deposit

Fig.7 Relationships between horizontal load and horizontal displacement at pile head 
ここに, $y$ : 杭頭変位, $y_{0}$ : 基準変位 $(1 \mathrm{~cm}), a$ : 係数, $x$ : 水平地 盤反力係数の非線形性に関する指数である。Fig.8 に示すように, 地盤の変形係数を(2)式の指針の方法で評価した場合, 特に粘性土に おいてばらつきが非常に大きく, 破線の評価線(指針)はデータの下 限に近い。水平載荷試験データから(18)式で累乗近似すると $a$ は 2.0 , $3.8, x$ は一 $-0.65,-0.86$ といずれも指針 $(a=1.0, x=-0.5)$ より大き くなっている。一方, 変形係数を(3), (4)式で評価すると, 相関係数
が大きくなりばらつきが小さくなっていることが分かる。

逆算 $k_{h}$ を，(1)’ 式(地盤の変形係数 $E_{S}$ は(15)式を使用)から算出し た推定 $k_{h 0}$ で除した逆算 $k_{h} /$ 推定 $k_{h 0}$ と, 杭頭変位の関係及び杭頭变位 /杭径の関係を砂質土と粘性土に分けて Fig.9，10 に示す。なお，(1) 式では, 指針の基準水平地盤反力係数は杭径の $3 / 4$ 乗に反比例する。 これは吉中が行った水平方向の平板載荷試験結果 ${ }^{3)}$ に基づいている。 指針の基になっている文献 3)では直径 $30 \mathrm{~cm}$ の平板載荷試験を基準

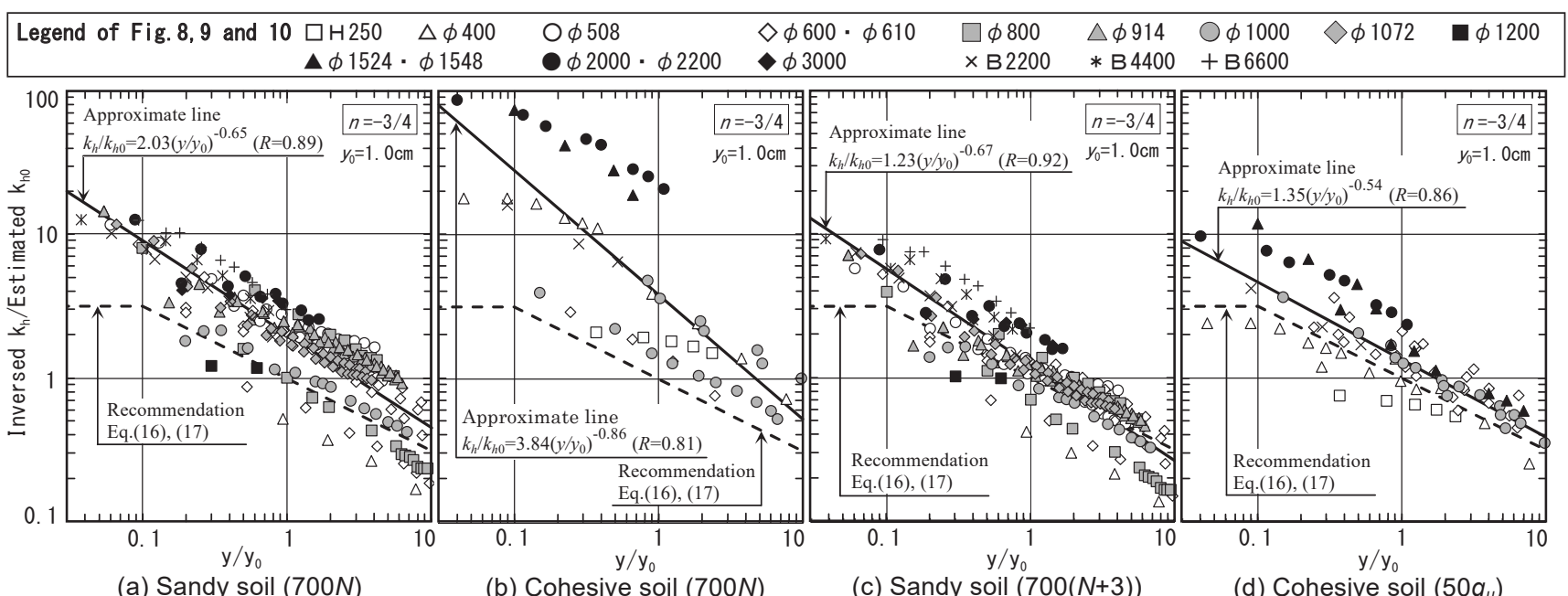

(a) Sandy soil $(700 N)$

(b) Cohesive soil $(700 \mathrm{~N})$

(c) Sandy soil $(700(N+3))$

(d) Cohesive soil $\left(50 q_{u}\right)$

Fig.8 Relationships between inversed $k_{h} /$ estimated $k_{h 0}$ and $y / y_{0}$

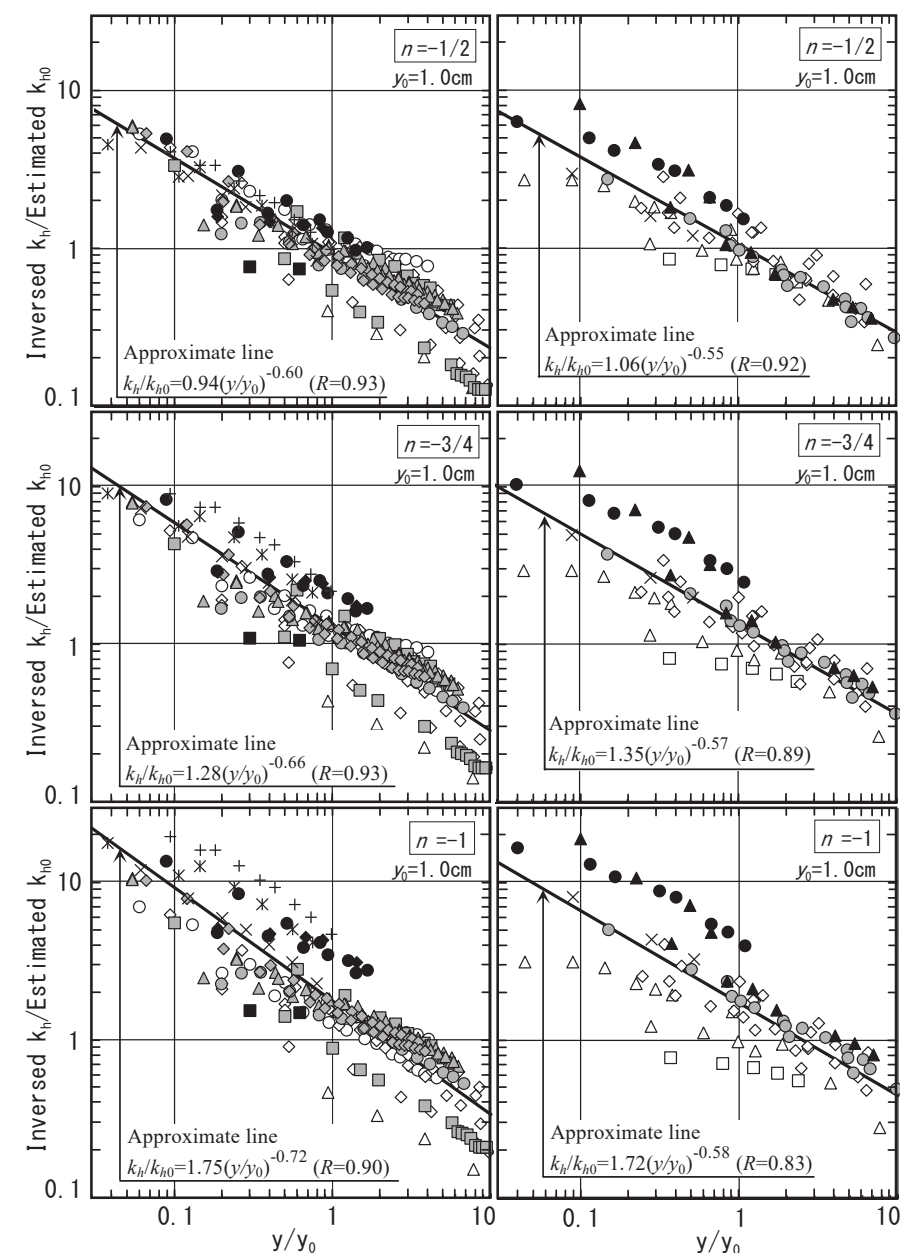

(a) Sandy soil $\left(E_{0} / 18\right)$

(b) Cohesive soil $\left(E_{0} / 18\right)$

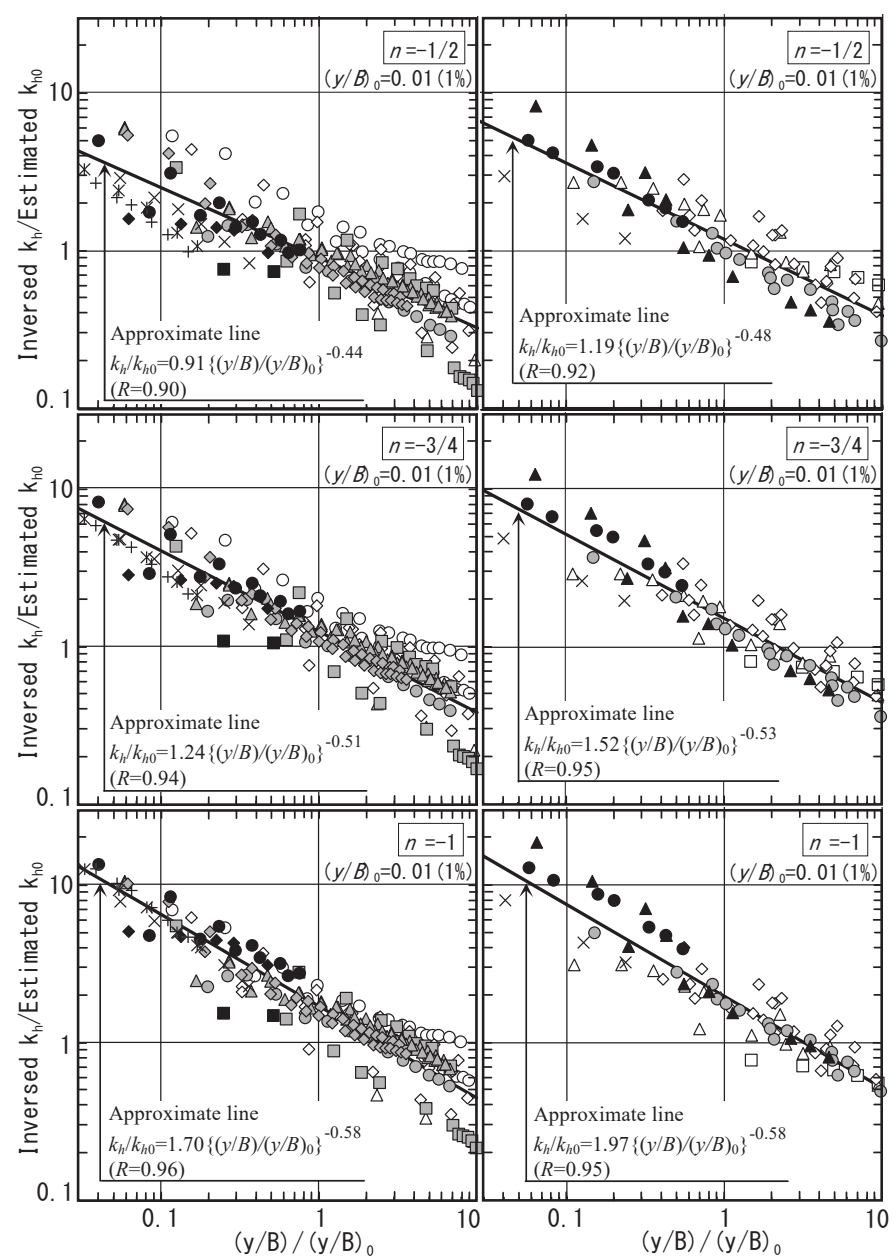

(a) Sandy soil $\left(E_{0} / 18\right)$ (b) Cohesive soil $\left(E_{0} / 18\right)$

Fig.9 Relationships between inversed $k_{h} /$ estimated $k_{h 0}$ and $y / y_{0} \quad$ Fig.10 Relationships between inversed $k_{h} /$ estimated $k_{h 0}$ and $(y / B) /(y / B)_{0}$ 
として(1)式を導いているので, $B=30 \mathrm{~cm}$ では $\bar{B}^{-1 / 2}, \bar{B}^{-3 / 4}, \bar{B}^{-1}$ で 水平地盤反力係数が同一となるようにすると，(19) (24)式 17),18) と なる。なお, (19)〜 (24)式は表記を揃えるため指針の $\bar{B} を B_{0}=1 \mathrm{~cm}$ と して $B / B_{0}$ に変えている。Fig.9, 10 では杭径の依存性についても検 討するため, 推定 $k_{h 0}$ の評価にはこれらの式を用いた。

(1)砂質土の場合と粘性土で $E_{S}=700 N$ 以外の場合

$$
\begin{aligned}
& k_{h 0}=34 E_{S}\left(B / B_{0}\right)^{-1 / 2} \\
& k_{h 0}=80 E_{S}\left(B / B_{0}\right)^{-3 / 4} \\
& k_{h 0}=187 E_{S}\left(B / B_{0}\right)^{-1}
\end{aligned}
$$

(2)粘性土で $E_{S}=700 \mathrm{~N}$ の場合

$$
\begin{aligned}
& k_{h 0}=26 E_{S}\left(B / B_{0}\right)^{-1 / 2} \\
& k_{h 0}=60 E_{S}\left(B / B_{0}\right)^{-3 / 4} \\
& k_{h 0}=140 E_{S}\left(B / B_{0}\right)^{-1}
\end{aligned}
$$

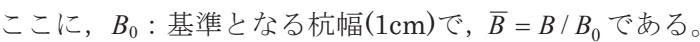

また, Fig.9には(18)式, Fig.10には下記の(25)式の最小二乗法に よる累乗近似式とその相関係数 $R$ を併記した。

$$
k_{h} / k_{h 0}=a\left\{(y / B) /(y / B)_{0}\right\}^{x}
$$

ここに, $a$ : 係数, $(y / B)_{0}$ : 基準となる $y / B(=0.01), x$ : 水平地盤反 力係数の非線形性に関する係数である。指針では(18)式において $a=1.0, x=-0.5$ であるが，水平載荷試験データから回帰すると(18) 式では $a=0.94 \sim 1.75, x=-0.55 \sim-0.72, \quad(25)$ 式では $a=0.91 \sim 1.97$, $x=-0.44 \sim-0.58$ である。

せん断波速度の実測值を用いていない影響も考えられるが, Fig.9, 10 より,地盤の変形係数を $E_{S}=E_{0} / 18$ として推定 $k_{h 0}$ を算定した方が, Fig.8(a)，(b)に示した指針の方法に比べて全体的にばらつきが小さ い。基準変位を指針では $1 \mathrm{~cm}^{12)}$, 道路橋示方書では杭径の $1 \%$ と) している。累乗近似式の杭径依存に関わる指数 $n$ が大きくなるにつ れて, 杭頭変位 $1 \mathrm{~cm}$ または杭頭変位/杭径 $1 \%$ 時の逆算 $k_{h}$ 推定 $k_{h 0}$ の 值は大きくなっている。累乗近似式の相関係数 $R$ は，横軸を杭頭変 位とした場合 $n=-1 / 2$ で，杭頭変位/杭径とした場合 $n=-1$ で最も高 くなっている。また, 横軸を杭頭変位とするよりも杭頭変位/杭径と する方が相関係数はやや高く, 杭頭変位/杭径で評価する場合, 杭径 の 1 乗に反比例させた基準水平地盤反力係数を用いた評価が最もば らつきが小さくなる。指針の水平地盤反力係数は，杭頭水平変位の $1 / 2$ 乗に反比例する非線形で評価することが推奨されている。Fig.9, 10 に示した累乗近似式において水平地盤反力係数は杭頭変位また は杭頭変位/杭径の $-0.44 \sim-0.72$ 乗に依存し, 砂質土と粘性土で大 きな違いは認められない。

以上の結果より，最もばらつきの小さい条件は横軸が杭頭変位で は杭径の-1/2 乗, 杭頭変位/杭径では杭径の- 1 乗であり, いずれ も傾きは一0.6 乗程度と指針よりも大きい。また，横軸を杭頭変位 とした場合，概小 $1 \mathrm{~cm}$ で，杭頭変位/杭径とした場合，概小 $0.03(3 \%)$ で縦軸は 1.0 となる。

\section{4. シミュレーション解析}

Table1 に示す全ての試験を対象に, Chang 式によるシミュレー ション解析を行った。解析条件は Table2 に示すように, Fig.8(a), (b)の条件(Case1), Fig.8(c), (d)の条件(Case2)と, Fig.9, 10 で砂 質土，粘性土ともにばらつきが小さかった杭頭変位で $\left(B / B_{0}\right)^{-1 / 2}$ (Case 3$)$, 杭頭変位/杭径で $\left(B / B_{0}\right)^{-1}(\mathrm{Case} 4)$ の 4 条件とした。水平地
盤反力係数 $k_{h}$ の杭頭変位または杭頭変位/杭径の依存性は, Case1, 2 では(16)，(17)式, Case3 では(18)式, Case4 では(25)式を用いた。

\begin{tabular}{|c|c|c|c|c|c|c|c|}
\hline \multirow[b]{2}{*}{ Case } & \multicolumn{2}{|c|}{$E_{S}$} & \multirow[b]{2}{*}{$\left(B / B_{0}\right)^{n}$} & \multirow[b]{2}{*}{$\mathrm{K}_{\mathrm{h} 0}$} & \multirow{2}{*}{$\begin{array}{c}\text { Ref. } \\
\text { disp. at } k_{h 0}\end{array}$} & \multirow[b]{2}{*}{$\mathrm{k}_{\mathrm{h}} / \mathrm{k}_{\mathrm{h} 0}$} & \multirow{2}{*}{$\begin{array}{l}\text { Legend } \\
\text { of Fig. } 11\end{array}$} \\
\hline & $\begin{array}{c}\text { Sandy } \\
\text { soil }\end{array}$ & $\begin{array}{c}\text { Cohesive } \\
\text { soil }\end{array}$ & & & & & \\
\hline 1 & \multicolumn{2}{|c|}{$700 \mathrm{~N}$} & $n=-3 / 4$ & Eq. $(20)(23)$ & $y_{0}=1 \mathrm{~cm}$ & Eq.(16)(17) & $-\cdots+\cdots$ \\
\hline 2 & $700(N+3)$ & $50 q_{u}$ & $n=-3 / 4$ & Eq.(20) & $y_{0}=1 \mathrm{~cm}$ & Eq.(16)(17) & $---\Theta-\cdot$ \\
\hline 3 & \multicolumn{2}{|c|}{$\mathrm{E}_{0} / 18$} & $n=-1 / 2$ & Eq.(19) & $y_{0}=1 \mathrm{~cm}$ & Eq.(18) & $\Delta$ \\
\hline 4 & \multicolumn{2}{|c|}{$E_{0} / 18$} & $\mathrm{n}=-1$ & Eq.(21) & $(\mathrm{y} / \mathrm{B})_{0}=3 \%$ & Eq.(25) & 曰 \\
\hline
\end{tabular}
Case 3, 4 については, 逆算 $k_{h}$ 推定 $k_{h 0}$ がほぼ 1.0 を通るように, (18) 式では $y_{0}=1 \mathrm{~cm},(25)$ 式では $(y / B)_{0}=0.03$ とし, 係数 $a=1.0$ とした。ま た，指数 $x$ は Fig.9, 10 より Case 3,4 ともに-0.6 とした。

解析結果の一例として, 砂質土 2 試験( $(\mathrm{S} 11, \mathrm{~S} 16)$, 粘性土 2 試験 （C11，C15）の杭頭荷重と地表面変位及び地中部最大曲げモーメン

Table 2 Simulation condition

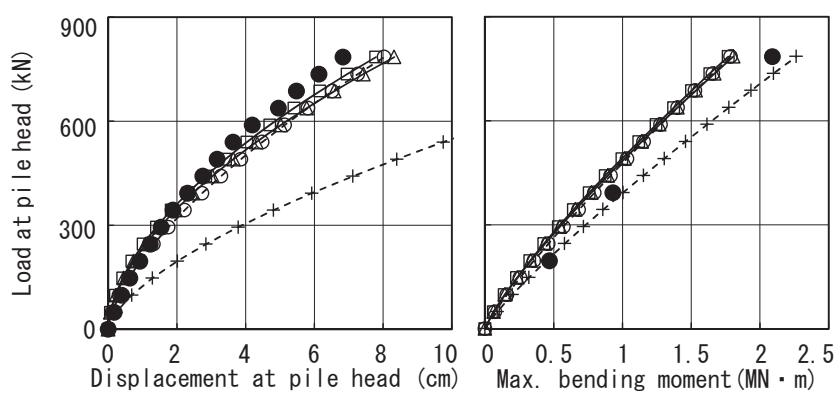

(a) Test No. S11

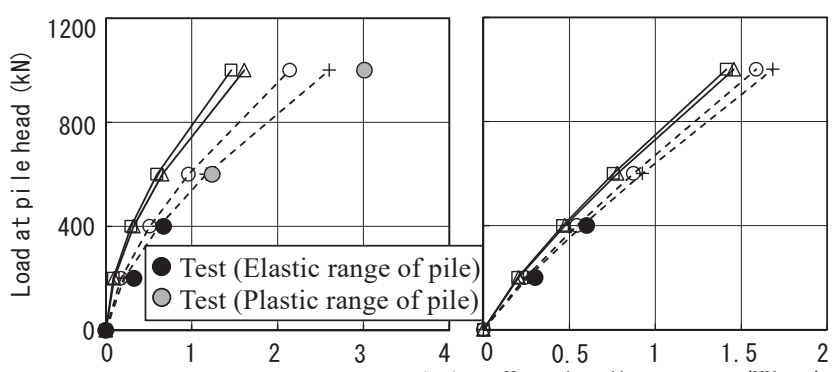

Displacement at pile head $(\mathrm{cm})$ Max. bending moment $(\mathrm{MN} \cdot \mathrm{m})$

(b) Test No. $\$ 16$

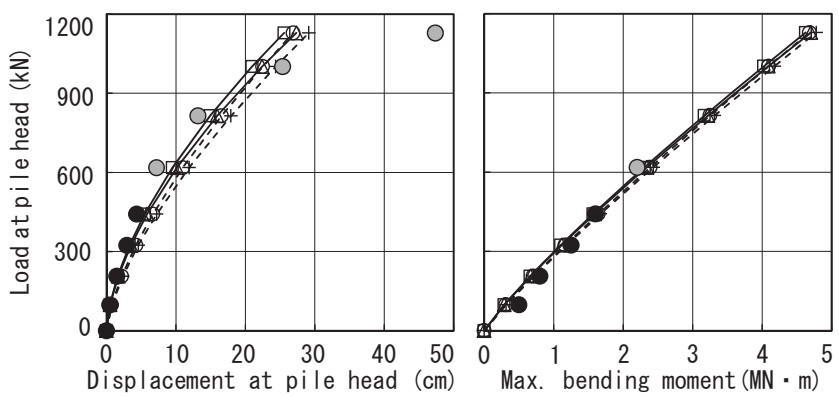

(c) Test No. C11

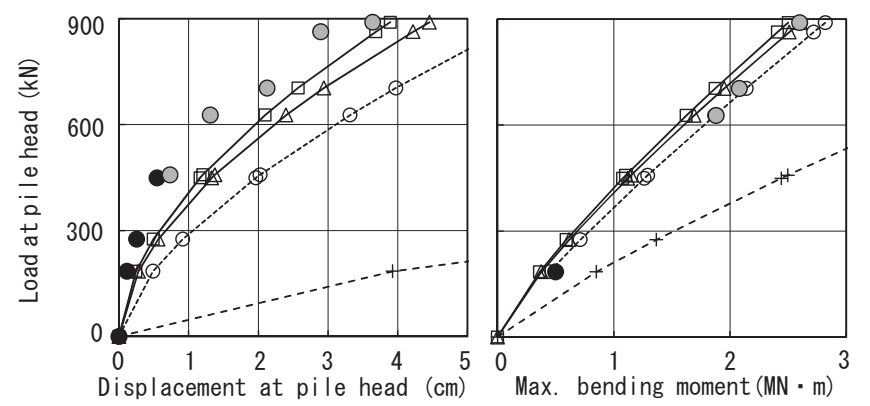

(d) Test No. C15

Fig.11 Examples of simulation results 
トの関係を Fig.11に示す。同図には, 杭が降伏した後の実測值も示 しており, 杭体が弾性範囲内を黒塗り (○), 降伏後を灰塗り $($ ○)で表 示した。杭の塑性化前は指針の方法(Case1) に比べて, せん断波速 度を用いた方法(Case 3, 4) は実測值と比較的良い対応を示し, Case3, 4 に有意な差は認められない。

全ケースの解析結果の内, 杭が弾性範囲内における杭頭変位と地 中部最大曲げモーメント及びその発生深度の実測值と解析值の比較 を Fig.12，13 に示す。なお，地中部最大曲げモーメントは Table1 に示寸砂質土 8 試験及び粘性土 6 試験で得られている。また, 地中 部最大曲げモーメント及びその発生深度の実測值は，全杭頭荷重で 示されている訳ではないため，部分的にデータが抜けている。 $E_{S}$ $=700 \mathrm{~N}$ とした Case 1 では杭頭変位のばらつきが非常に大きく, 著者 らの既往の研究による提案 ${ }^{17)}$,18) である Case2, せん断波速度を用い
た Case3，4 ではばらつきは大きいものの，近似線の傾きは $1.0 \sim$ 1.1 と平均的に見れば解析值と実測值はほぼ対応している。また, Case1〜4 の地中部最大曲げモーメントは, 杭頭変位ほどのばらつ きは認められず，回帰線の傾きはいずれも $0.9 \sim 1.1$ である。一方， 地中部最大曲げモーメント発生深度の解析值は, 実測值に比べて Case1 ではばらつきが大きく平均的にはやや深め, Case2〜4 では 浅めになる傾向を示した。これは, Case1では水平地盤反力係数を 小さめに評価しているためと判断できる。また, Case2〜4 で杭頭 変位や地中部最大曲げモーメントが一致しているにもかかわらず最 大曲げモーメント発生深度が浅めになるのは, Chang 式では一様地 盤が一様に剛性低下寸るからで, 深部地盤の変形係数を過小評価し ているためと判断される。

曲げモーメント分布の一例として, Fig.14 S 10 及び C11 の結

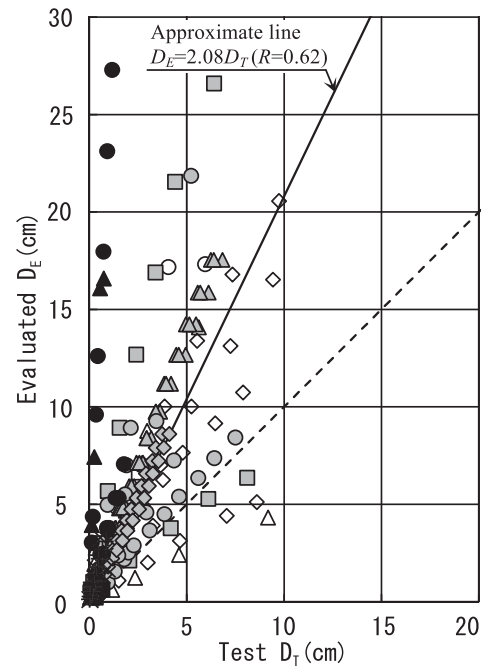

(a) Case 1

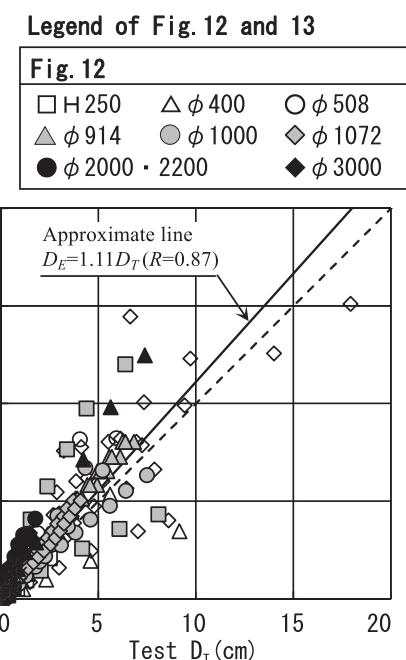

(b) Case2

Fig.12 Comparisons of displacement $D$ at pile head between test data and evaluated data
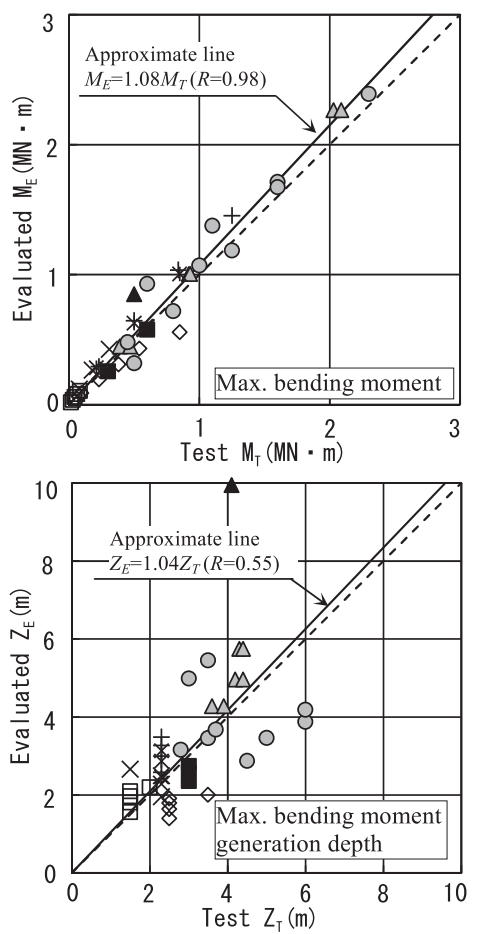

(a) Case 1
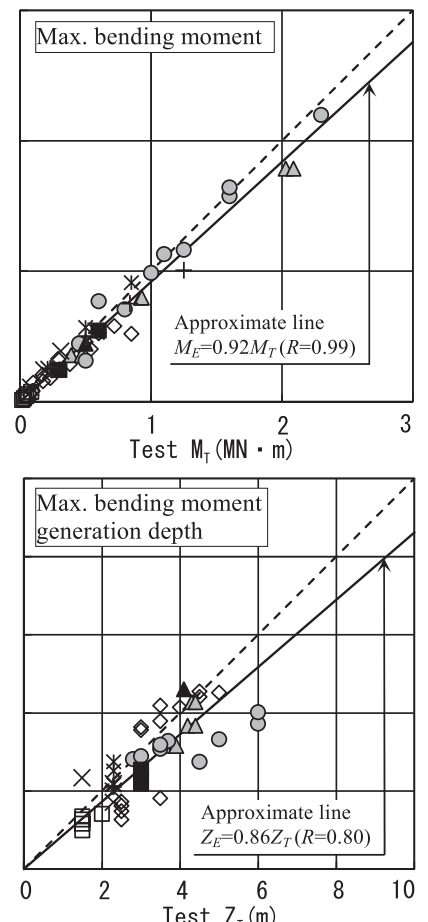

(b) Case2
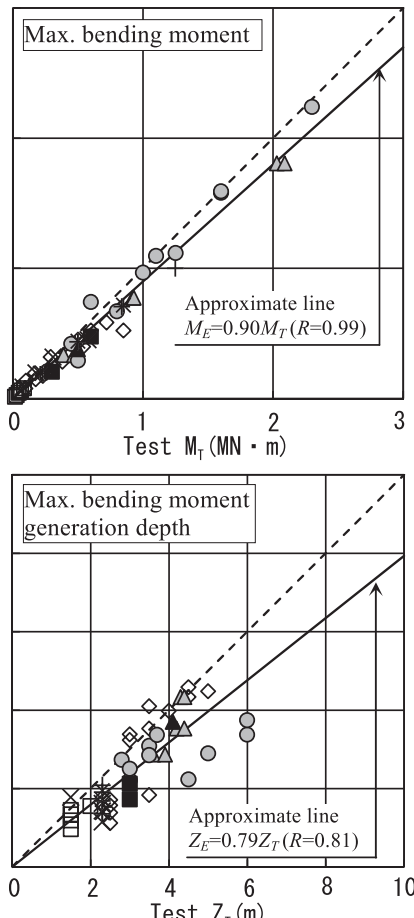

(c) Case 3
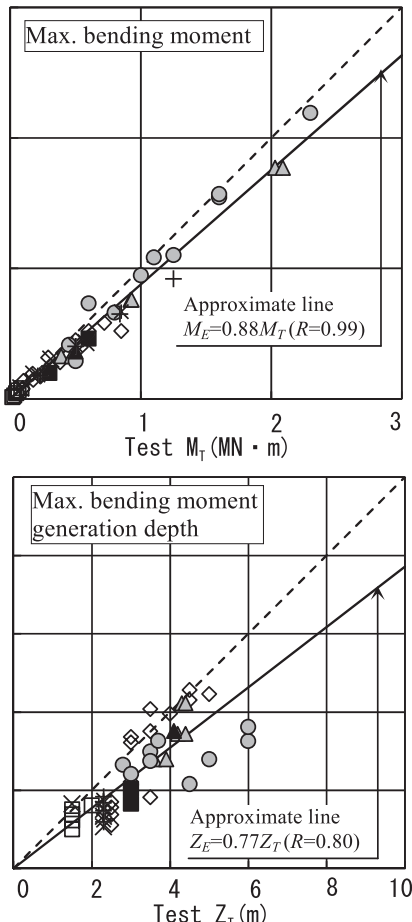

(d) Case 4

Fig.13 Comparisons of max. bending moment $M$ and its generation depth $Z$ between test data and evaluated data 


\begin{tabular}{|c|c|c|c|c|c|c|c|}
\hline & S10 & C11 & Test & Case1 & Case2 & Case3 & Case4 \\
\hline \multirow{2}{*}{$\begin{array}{c}\text { Load at } \\
\text { pile head }\end{array}$} & $196 \mathrm{kN}$ & $98 \mathrm{kN}$ & $\bullet$ & $\boldsymbol{\bullet . \bullet}$ & $\circ 00$ & $\cdots \cdots \cdots$ & $\bullet \bullet \bullet$ \\
\cline { 2 - 8 } & $392 \mathrm{kN}$ & $196 \mathrm{kN}$ & $\triangle$ & $\mathbf{- - -}$ & $\times \times \times$ & ---- & $\boldsymbol{-}$ \\
\cline { 2 - 8 } & $785 \mathrm{kN}$ & $324 \mathrm{kN}$ & $\mathbf{\square}$ & - & +++ & - & \\
\hline
\end{tabular}
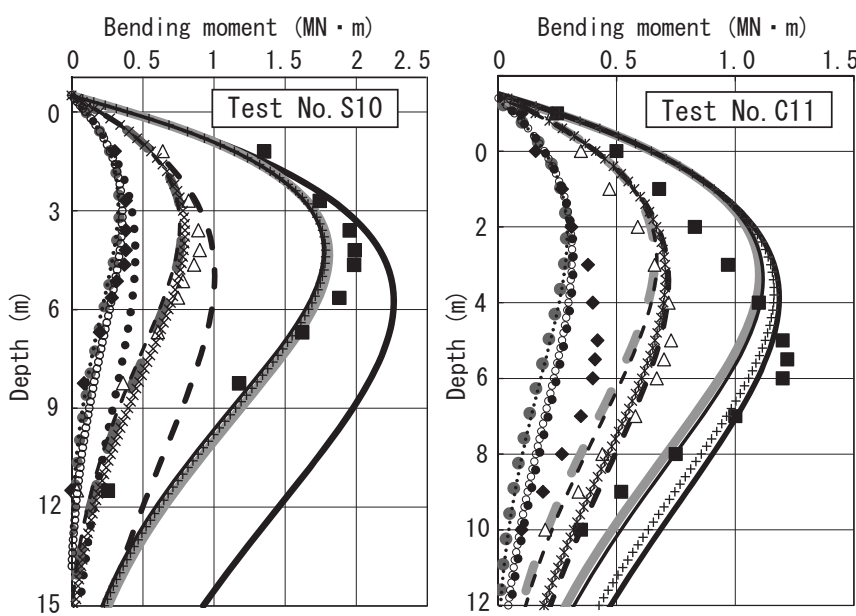

Fig.14 Examples of distribution of bending moment

果を示す。Case1 は Case2〜 4 と比べて地中部最大曲げモーメント 発生深度が深くなり，それに伴って最大曲げモーメントも大きくな る傾向が認められる。一方, Case 2 ～ 4 の最大曲げモーメントはほ ぼ同じであり，実測值に比べてやや過小評価となっている。

\section{5. 評価法の提案}

前章までの検討結果から, Chang 式に用いる地盤の変形係数と水 平地盤反力係数の評価方法として, 以下の 2 種類を提案する。

- 地盤の変形係数 $E_{S}\left(\mathrm{kN} / \mathrm{m}^{2}\right)$ の評価方法

$$
E_{S}=E_{0} / 18
$$

ここに, $E_{0}$ : せん断波速度から求めた地盤の初期変形係数 $\left(\mathrm{kN} / \mathrm{m}^{2}\right)$ である。

- 水平地盤反力係数の評価方法

(1)方法 A

$$
\begin{aligned}
& k_{h 0}=34 E_{S}\left(B / B_{0}\right)^{-1 / 2} \\
& k_{h}=k_{h 0}\left(y / y_{0}\right)^{-0.6} \\
& k_{h, \text { max }}=18 k_{h 0}
\end{aligned}
$$

(2)方法 B

$$
\begin{aligned}
& k_{h 0}=187 E_{S}\left(B / B_{0}\right)^{-1} \\
& k_{h}=k_{h 0}\left\{(y / B) /(y / B)_{0}\right\}^{-0.6} \\
& k_{h, \text { max }}=18 k_{h 0}
\end{aligned}
$$

ここに, $k_{h 0}$ : 基準水平地盤反力係数(基準変位 $\left(y_{0},(y / B)_{0}\right)$ 時の水平 地盤反力係数), $y$ : 杭頭変位 $(\mathrm{cm}), y_{0}: 1 \mathrm{~cm}, B:$ 杭径 $(\mathrm{cm}), B_{0}: 1 \mathrm{~cm}$, $(y / B)_{0}: 0.03, k_{h, \max }$ : 最大水平地盤反力係数である。最大水平地盤反 力係数は，地盤の初期変形係数 $E_{0}$ を用いた值とした。

逆算 $k_{h}$ を，(28)，(29)式と(31)，（32)式(地盤の変形係数 $E_{S}$ は(26)

\begin{tabular}{|c|c|c|c|c|}
\hline-1250 & $\triangle \phi 400$ & Оధ508 & $\diamond \phi 600 \cdot \phi 610$ & $\square \phi 800 \quad \triangle \phi 914$ \\
\hline$\phi 1000$ & $\nabla \phi 1072$ & $\phi 1200$ & $\Delta \phi 1524 \cdot \phi 1548$ & $\phi 2000 \cdot \phi 2200$ \\
\hline$\phi 3000$ & $\times$ B 2200 & * B 4400 & $+\mathrm{B} 6600$ & \\
\hline
\end{tabular}
式を使用)から算出した推定 $k_{h 0}$ で除した逆算 $k_{h} /$ 推定 $k_{h 0}$ と杭頭変位 の関係及び杭頭変位/杭径の関係を砂質土と粘性土を合わせて Fig.15 に示す。Fig.15には，(28)，(29)式と(31)，(32)式に示した提 案線を併記している。方法 $\mathrm{A}$ では基準変位 $y_{0}=1 \mathrm{~cm}$ で, 方法 $\mathrm{B}$ では 基準変位 $(y / B)_{0}=0.03(3 \%)$ で $k_{h} / k_{h 0}=1.0$ となる関係になっており, 実 測值と広範囲にわたってよい対応を示している。また，本評価法は

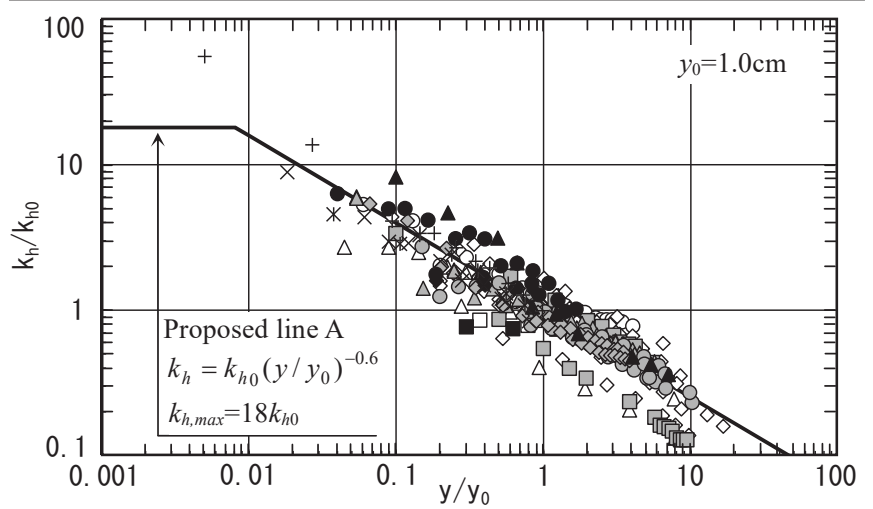

(a) Proposed method A

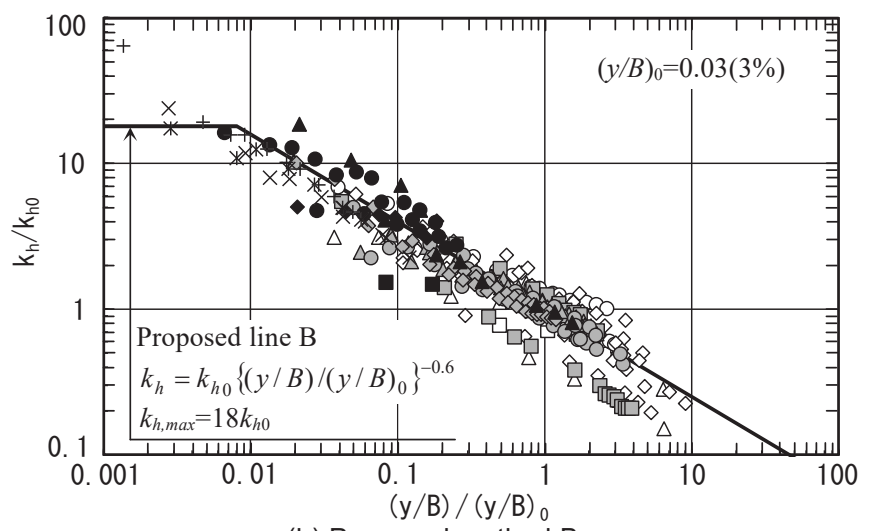

(b) Proposed method $B$

Fig.15 Proposed lines of relation between $k_{h} / k_{h 0}$ and $y / y_{0}$ or $(y / B) /(y / B)_{0}$

砂質土と粘性土を区別する必要はない。

6. まとめ

本研究では, 既往の孔内水平載荷試験から得られる変形係数とせ 几断波速度から得られる変形係数の比較から, 地盤の変形係数算定 にせん断波速度を用いる方法を提案した。さらに，杭頭自由条件の 単杭の水平載荷試験結果に基づき, Chang 式 12),13)を用いた逆解析 から逆算水平地盤反力係数を求め, 大口径杭まで含めた水平地盤反 力係数の設定方法を提案した。得られた知見は以下の通りである。

1）孔内水平載荷試験から得られる変形係数 $E_{b}$ は, 地盤のひずみ 依存性を考慮することで精度向上が図れ, せん断波速度から求 まる $E_{0}$ に対して $1 / 18$ 程度となる。

2）基準変位が杭頭変位 $1 \mathrm{~cm}$ の場合, 杭径依存性を $\left(B / B_{0}\right)^{-1 / 2}$, 杭 頭変位による非線形性を $\left(y / y_{0}\right)^{-0.6}$ としたケースでばらつきが小 さな水平地盤反力係数〜杭頭変位関係が得られた。一方，基準 変位を杭頭変位/杭径の $3 \%$ とした場合, 杭径依存性を $\left(B / B_{0}\right)^{-1}$, 杭頭変位による非線形性を $\left\{(y / B) /(y / B)_{0}\right\}^{-0.6}$ としたケースでばら つきが小さな水平地盤反力係数〜杭頭変位/杭径関係が得られ た。しかし, 両者の優劣は水平載荷試験データの分析からでは 判断できない。

3) Chang 式による杭の水平抵抗評価に用いる水平地盤反力係数 の算定にせん断波速度を用いる方法を提案した。この提案式を 用いた杭頭自由条件の Chang 式によるシミュレーション解析 
では，杭頭変位を平均的な值よりやや大きめに，地中部最大曲 げモーメントをやや小さめに，さらに地中部最大曲げモーメン 卜発生深度を浅めに評価する傾向がある。

4）検討対象は杭頭自由条件に限られ，さらに上記傾向が有るが, 地表付近の地盤がほぼ一様と見なせ, 地盤変形の影響が小さく, 杭が弾性範囲内の場合には, Chang 式は地盤の非線形挙動を考 慮した杭の水平抵抗評価にも有用であることが示唆される。

なお，今後は杭頭固定条件や地盤変位の影響があるケースの適用 性に加えて, 一様でない地盤にも適用可能な梁ばねモデルとの対応 を検討する予定である。また, 杭の大口径化に伴い, 曲げ変形のみ でなくせん断変形を考慮した検討が必要であるが，これは今後の課 題としたい。

\section{謝辞}

本研究を行うにあたり, 実測データの提供にご協力頂いた東京ソ イルリサーチの田部井哲夫氏，吉田正氏に謝意を表します。

\section{参考文献}

1) A. B. Vesic: Bending of Beams Resting on Isotropic Elastic Solid, Journal of the Engineering Mechanics Division, ASCE, Vol.87, No.EM2, pp.35-53, 1961.4

2) A. J. Francis: Analysis of Pile Groups with Flexural Resistance, Journal of the Soil Mechanics and Foundation Division, ASCE, Vol.90, No.SM3, pp.1-32, 1964.5

3) Yoshinaka, R.: Coefficient of Subgrade Reaction Considering Scale effect, Technical Note of Public Works Research Institute, No.299 (in Japanese) 吉中竜之進：地盤反力係数と，その載荷幅による補正，土木研究所資料， 第 299 号, 1967.7

4) Kubo, K.: A New Method for the Estimation of Lateral Resistance of Piles, Report of port and harbor technical research institute ministry of transportation, Vol.2, No.3, 1964.3 (in Japanese) 久保浩一: 〈いの横抵抗の新しい計算法, 港湾技術研究所報告, Vol.2, No.3, 1964.3

5) Okahara, M., Takagi, S., Nakatani, S., Taguchi, K. and Sakamoto, A.: Investigation for Horizontal Resistance of Pile based on Horizontal Load Test Data, Technical Note of Public Works Research Institute, No.2721, 1989.1 (in Japanese)

岡原美知夫, 高木章次, 中谷昌一, 田口敬二, 坂本昭夫 : 載荷試験データに よる杭の水平抵抗特性に関する調査, 土木研究所資料, 第 2721 号, 1989.1

6) Nakatani, S., Shirado, M., Kono, T., Nakamura, T., Nomura, T., Yokomaku, K. and Iochi, H.: Survey on horizontal resistance characteristics of piles based on loading test data, Technical Note of Public Works Research Institute, No.4136, 2009.3 (in Japanese)

中谷昌一, 白戸真大, 河野哲也, 中村祐二, 野村朋之, 横幕清, 井落久貴 : 性能規定体系における道路橋基礎の安定照査法に関する研究，土木研究 所資料，第 4136 号, 2009.3

7) Koseki, J., Kurachi, S. and Ogata, T.: Influence of Stress and Strain Level Dependency of Deformation Characteristics of Subsoil on Scale Effect of Subgrade Reaction Coefficient, The Foundation Engineering \& Equipment, Vol.33, No.12, pp.26-29, 2005.12 (in Japanese)

古関潤一, 倉知禎直, 緒方辰男: 地盤反力係数の寸法効果に及ぼす地盤変 形特性の応力レベル依存性と非線形性の影響, 基礎工, Vol.33, No.12, pp.26-29, 2005.12

8) Kishida, H. and Nakai, S.: Analysis of a Laterally Loaded Pipe with Non-linear Subgrade Reaction, Transactions of the Architectural Institute of Japan, No.281, pp.41-55, 1979.7 (in Japanese)

岸田英明, 中井正一：地盤の破壊を考慮した杭の水平抵抗，日本建築学会 論文報告集, No.281, pp.41-55, 1979.7

9) Koda, M., Takemura, J. and Kusakabe, O.: Modeling and Evaluation of p-y Curves of Single Pile in Sand, Journal of Japan Society of Civil Engineers, No.645/III-50, pp.191-207, 2000.3 (in Japanese)

神田政幸, 竹村次郎，日下部治: 砂地盤中の単杭の p-y 関係のモデル化，土 木学会論文集, No.645/III-50, pp.191-207, 2000.3

10) Seki, T., Motoi, Y., and Suzuki, N.: Modeling of Relationship between
Displacement and Subgrade Reaction for Analysis of Laterally Loaded Single Piles, Journal of Structural Engineering B, Architectural Institute of Japan, Vol.58B, pp.133-138, 2012.3 (in Japanese)

関崇夫, 元井康雄, 鈴木直子 : 単杭の水平抵抗解析に用いる地盤反力変位 関係のモデル化, 構造工学論文集, Vol.58B, pp.133-138, 2012.3

11) Mase, T. and Nakai, S.: Examination of Soil Spring Setting Method of Single Pile, Journal of Structural and Construction Engineering (Transactions of AIJ), Vol.77, No.680, pp.1527-1535, 2012.10 (in Japanese)

間瀬辰也, 中井正一: 単杭の杭周地盤ばねの評価法に関する検討, 日本建 築学会構造系論文集, 第 77 巻, 第 680 号, pp.1527-1535, 2012.10

12) Architectural Institute of Japan: Recommendations for Design of Building Foundations, pp.267-280, 2001.10 (in Japanese)

日本建築学会 : 建築基礎構造設計指針, pp.267-280, 2001.10

13) Y. L. Chang: Discussion on "Lateral Pile Loading Tests" by L. B. Feagin, A.S.C.E Transaction Vol.102, pp.272-278, 1937

14) Architectural Institute of Japan: Ultimate Strength and Deformation Capacity of Building in Seismic Design (1990), 164p, 1990.10 (in Japanese)

日本建築学会 : 建築耐震設計における保有水平耐力と変形性能（1990）, $164 \mathrm{p}, 1990.10$

15) Japan Road Association: Specifications for Highway Bridges, Part IV Substructures, pp.284-287, 2012.3 (in Japanese)

日本道路協会 : 道路橋示方書, IV下部構造編, pp.284-287, 2012.3

16) Railway technical research institute: Design Standards for Railway Structures and Commentary (Foundation Structure), pp.247-330, 2012.4 (in Japanese) 鉄道総合技術研究所編：鉄道構造物等設計標準 - 同解説, 基礎構造物, pp.247-330, 2012.4

17) Shimomura, S. and Suzuki, Y.: Coefficient of Subgrade Reaction Estimated from Horizontal Load Test Data of Single Piles with Wide range Diameter in Sand Deposit, AIJ Journal of Technology and Design, Vol.22, No.52, pp.919-924, 2016.10 (in Japanese)

下村修一, 鈴木康嗣 : 広範囲な杭径の水平載荷試験結果に基づく砂質土地 盤における単杭の水平地盤反力係数, 日本建築学会技術報告集, 第 22 巻, 第 52 号, pp.919-924, 2016.10

18) Shimomura, S. and Suzuki, Y.: Coefficient of Subgrade Reaction Estimated from Horizontal Load Test Data of Single Piles with Wide range Diameter in Cohesive Soil Deposit, AIJ Journal of Technology and Design, Vol.23, No.53, pp.93-98, 2017.2 (in Japanese)

下村修一, 鈴木康嗣 : 広範囲な杭径の水平載荷試験結果に基づく粘性土地 盤における単杭の水平地盤反力係数, 日本建築学会技術報告集, 第 23 巻, 第 53 号, pp.93-98, 2017.2

19) JGS 1531-2012: Pressuremeter test to evaluate index of the ground, Japanese Geotechnical Society, 2012

20) Tabei, T., Uchida, A., Kobayashi, H. and Hatanaka, M.: Strain Level of Deformation Modulus for Cohesive Soils Obtained by Soil Investigation, Summaries of Technical Papers of Annual Meeting, Architectural Institute of Japan, Structure- I , pp.413-414, 2011.8 (in Japanese)

田部井哲夫, 内田明彦, 小林治男, 畑中宗憲 : 地盤調査から求めた粘性土 地盤の変形係数とひずみレベル, 日本建築学会大会学術講演梗概集, 構造 I , pp.413-414, 2011.8

21) Koyamada, K., Miyamoto, Y. and Miura, K.: Nonlinear Property for Surface Strata from Natural Soil Samples, 38th Japan National Conference on Geotechnical Engineering, pp.2077-2078, 2003.7 (in Japanese)

古山田耕司, 宮本裕司, 三浦賢治 : 多地点での原位置採取試料から評価し た表層地盤の非線形特性, 第 38 回地盤工学研究発表会, pp.2077-2078, 2003.7

22) Imazu, M. and Fukutake, K.: Dynamic Shear Modulus and Damping of Gravel Materials, 21th Japan National Conference on Geotechnical Engineering, pp.509-512, 1986.6 (in Japanese)

今津雅紀, 福武毅芳: 砂碟材料の動的変形特性, 第 21 回土質工学研究発表 会, pp.509-512, 1986.6

23) Hara, A.: Dynamic Characteristics of Soils and Response Analysis of Soil Deposits, Doctoral Thesis, University of Tokyo, 1980.12 (in Japanese) 原昭夫 : 土の動的変形特性と地盤の応答解析に関する研究, 東京大学学位 論文, 1980.12

24) Japan Road Association: Specifications for Highway Bridges, Part V Seismic Design, pp.32-33, 2012.3 (in Japanese)

日本道路協会 : 道路橋示方書, V 而震設計編, pp.32-33, 2012.3

25) Imai, T.: P- and S-Wave Velocities of the Ground in Japan, Proceedings of the 9th International Conference on Soil Mechanics and Foundation Engineering,Vol.2, pp.257-260, 1977 


\section{HORIZONTAL RESISTANCE OF PILE EVALUATED BY CHANG'S FORMULA USING COEFFICIENT OF SUBGRADE REACTION CALCULATED FROM SHEAR WAVE VELOCITY}

\section{Shuichi SHIMOMURA* and Yasutsugu SUZUKI**}

* Assist. Prof., Dept. of Architecture and Architectural Engineering, College of Industrial Technology, Nihon University, Dr.Eng.

** General Manager, Disaster Prevention and Wind Engineering Group, Kajima Technical Research Institute, Dr.Eng.

In seismic design of pile foundation by static stress analysis, a model in which a pile is a beam and the beam and the ground are connected by multiple springs (coefficient of subgrade reaction $k_{h}$ ) is used as a practical design. The stress and horizontal displacement of the piles obtained from this method strongly depends on the evaluation accuracy of the coefficient of subgrade reaction $k_{h}$ as well as the specification section of the pile body. In this study, we propose a method to evaluate coefficient of subgrade reaction $k_{h}$ based on shear wave velocity. We also propose a method to evaluate $k_{h}$ from the inverse analyses based on the Chang's formula using the results of past horizontal loading test data of single piles with rotatable pile head condition including large diameter piles performed at in situ. The following conclusions are obtained.

(1) The deformation modulus $E_{b}$ obtained from the pressuremeter test can be suppressed its variation by considering the strain dependency of the ground rigidity. $E_{b}{ }^{\prime}$ is about 1/18 in sandy and cohesive soils, compared with $E_{0}$ obtained from shear wave velocity.

(2) In the case where the reference displacement is set to $1 \mathrm{~cm}$ for the displacement at pile head, the relationship between the coefficient of subgrade reaction and the pile head displacement with small variation can be obtained in the case where the pile diameter dependence is set to $\left(B / B_{0}\right)^{-1 / 2}$ and the nonlinearity due to the displacement at pile head is set to $\left(y / y_{0}\right)^{-0.6}$. On the other hand, when the reference displacement is set to $3 \%$ of the displacement at pile head / pile diameter, in the case where the pile diameter dependence is set to $\left(B / B_{0}\right)^{-1}$ and the nonlinearity due to the displacement at pile head is set to $\{(y / B) /(y / B)\}^{-0.6}$, small variation of relationship between coefficient of subgrade reaction and displacement at pile head / pile diameter is obtained. However, superiority and inferiority of both can not be judged only from analysis of horizontal load test data.

(3) A calculation method of the coefficient of subgrade reaction using shear wave velocity for evaluate horizontal resistance of piles by the Chang's formula is proposed. Comparing with the actual measured values under rotatable pile head condition, the simulation analysis values by the proposed method and the Chang's method show that the pile head displacement is slightly larger, the maximum bending moment is slightly smaller and the maximum bending moment generation depth is shallower.

(4) Although the subjects are for only the rotatable pile head condition and the above tendency is observed. But the Chang's formula is useful for evaluate the horizontal resistance of the elastic pile considering the nonlinear behavior of the ground if the ground near the ground surface can be regarded as almost uniform and the influence of the ground deformation is small. 